\title{
Development of a coal reserve GIS model and estimation of the recoverability and extraction costs
}

\author{
Chandrakanth Reddy Apala \\ West Virginia University
}

Follow this and additional works at: https://researchrepository.wvu.edu/etd

\section{Recommended Citation}

Apala, Chandrakanth Reddy, "Development of a coal reserve GIS model and estimation of the recoverability and extraction costs" (2009). Graduate Theses, Dissertations, and Problem Reports. 2062. https://researchrepository.wvu.edu/etd/2062

This Thesis is protected by copyright and/or related rights. It has been brought to you by the The Research Repository @ WVU with permission from the rights-holder(s). You are free to use this Thesis in any way that is permitted by the copyright and related rights legislation that applies to your use. For other uses you must obtain permission from the rights-holder(s) directly, unless additional rights are indicated by a Creative Commons license in the record and/ or on the work itself. This Thesis has been accepted for inclusion in WVU Graduate Theses, Dissertations, and Problem Reports collection by an authorized administrator of The Research Repository @ WVU. For more information, please contact researchrepository@mail.wvu.edu. 
Development of a Coal Reserve GIS Model and Estimation of the Recoverability and Extraction Costs

Apala Chandrakanth Reddy

\author{
Thesis submitted to the \\ College of Engineering and Mineral Resources \\ West Virginia University \\ in partial fulfillment of the requirements \\ for the degree of \\ Master of Science \\ in \\ Mining Engineering
}

\begin{abstract}
Dr. Yi Luo, Ph.D., Chair,
Dr. Felicia F. Peng, Ph.D.,

Dr. Brijes Mishra, Ph.D.
\end{abstract}

Department of Mining Engineering

Morgantown, West Virginia

2009

Keywords: Resources; ARC GIS; Recoverability; Ventilation costs 


\section{ABSTRACT \\ Development of a Coal Reserve GIS Model and Estimation of the Recoverability and Extraction Costs}

\section{Apala Chandrakanth Reddy}

The United States has the world largest coal resource and coal will serve as the major and dependable energy source in the coming 200 years or more. However, the amount of recoverable coal reserve depends on the geological formations and quality of the coal seams, future development of mining technology and the extraction cost. A NETL sponsored cooperative research was conducted by the researchers at Carnegie Mallon University (CMU) and West Virginia University (WVU) to estimate the recoverable coal reserve. This thesis presents some of the works that WVU performed to enhance the coal reserve model including characterization of coal reserves, estimation of recovery ratio and extraction cost.

To characterize the coal reserve, a GIS model was developed. In this model, information of coal reserve, rank, gas content, etc. have been collected from published sources and integrated into a combined coal reserve database. A GIS interface has been developed to interact with the database to display the needed information in map forms.

Room and pillar mining method could still remain to be the main method to mine small and difficult reserves. To maximize the coal reserve recovery by designing proper sized coal pillars is the most important task in room and pillar mining operation. Though pillar design methodology has been proposed long time ago, it needs an iterative solution process. To facilitate programming the coal reserve model and engineering application, a straight-forward pillar design method was developed.

Mine ventilation often is a limiting factor for underground coal mine operations. Ventilation requirement for an underground coal mine (i.e., fan head and quantity) depends on the gas content and production rate. A method to estimate the ventilation requirement in mine planning stage described in the SME handbook has been modified to take the variation of coal seam gas content into consideration. It should be noted that the gas content of a coal seam depends on the coal rank and the average burial depth. Again, the method was made easy to be programmed into the coal reserve model and to be applied by engineers. 


\section{Acknowledgements}

I want to express my sincere gratitude and appreciation to my academic advisor, Dr. Yi Luo, for his persistent encouragement, support and guidance during the period of graduate study and thesis work. He is one of the best teachers I ever saw since my childhood. He is a wonderful person in the academic field and a great motivator. I learned a lot from his hard working and great personality. I can say it is my luck and pleasure to have him as my teacher.

I would like to thank Dr. Felicia F. Peng, and Dr. Brijes Mishra for their valuable and constructive suggestions, comments and advices. 


\section{Table of Contents}

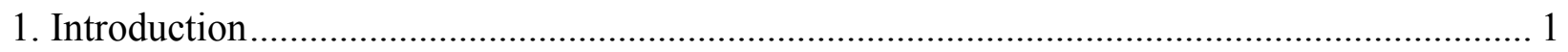

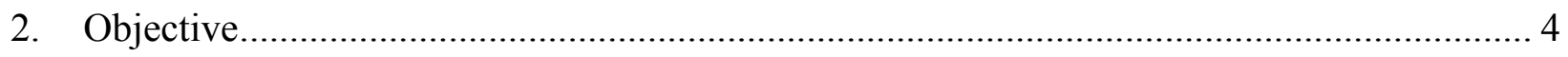

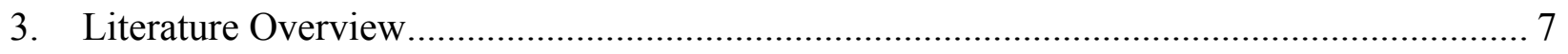

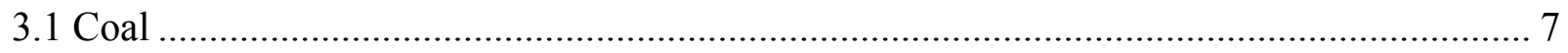

3.2 Distribution of Coal Reserves in United States..................................................... 8

3.3 Mineable Coal seams in US and their Rank Information............................................ 14

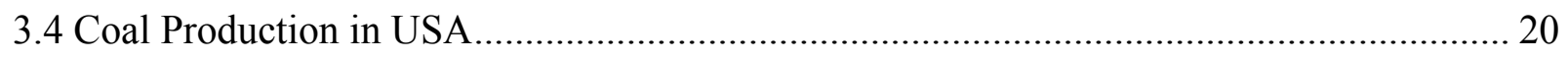

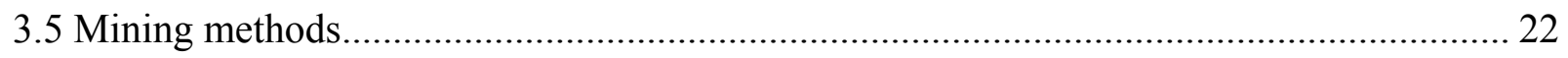

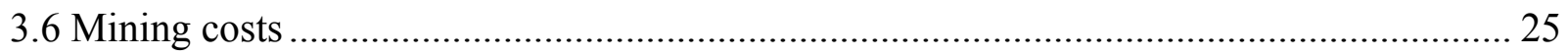

3.7 Previous Cost Models........................................................................................... 26

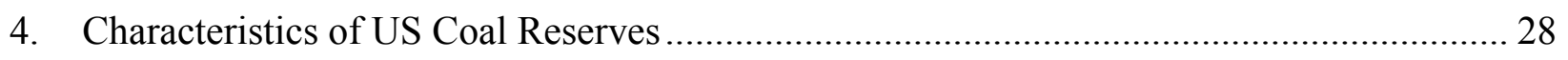

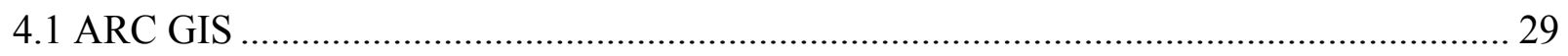

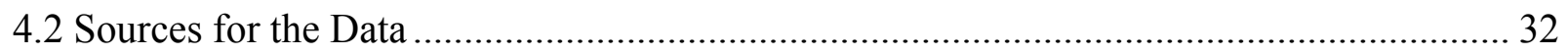

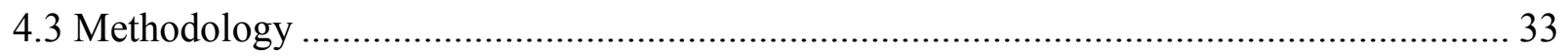

4.4 Results................................................................... 33

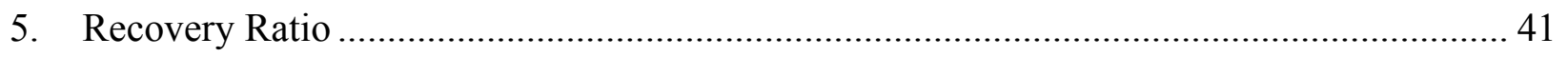




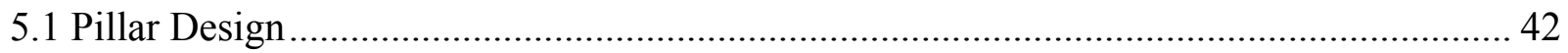

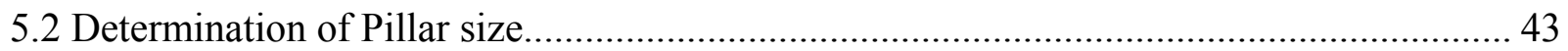

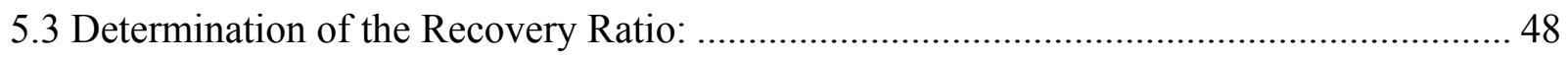

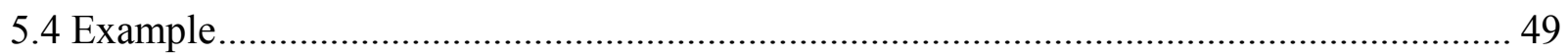

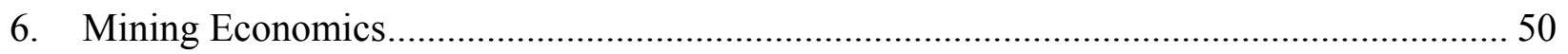

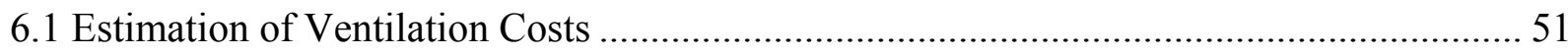

6.2 Base method for Estimating Ventilation Requirement .................................................... 51

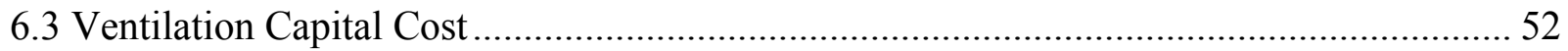

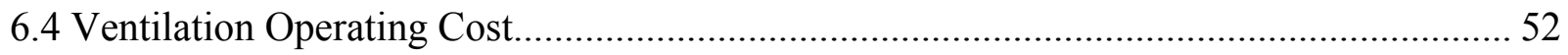

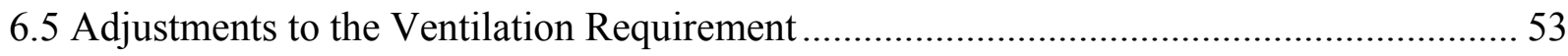

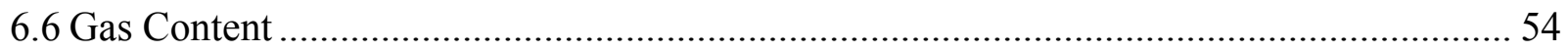

6.7 Indirect method to Estimate Gas Content ………….................................................... 54

6.8 Correction Factor to Ventilation Air Quantity: ………………..................................... 56

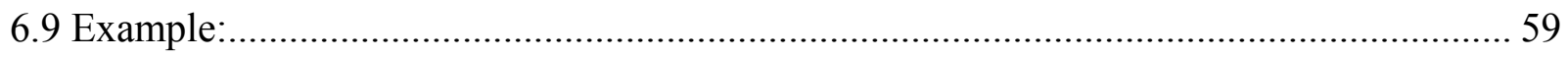

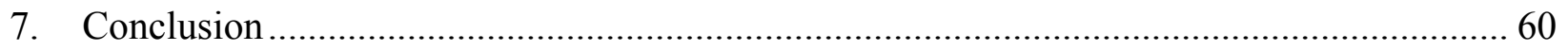

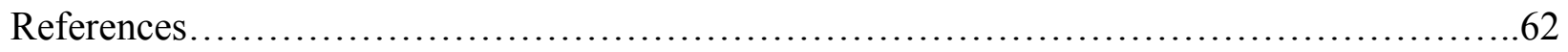

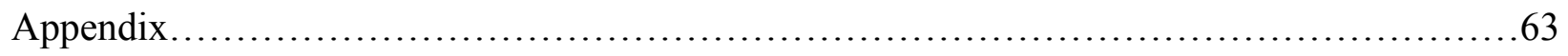




\section{TABLE OF FIGURES}

Figure 1: Delineation of U.S. Coal Resources and Reserves ${ }^{5}$, EIA 1997............................... 12

Figure 2: Coal-Bearing Areas of the United States ${ }^{5}$.......................................................... 13

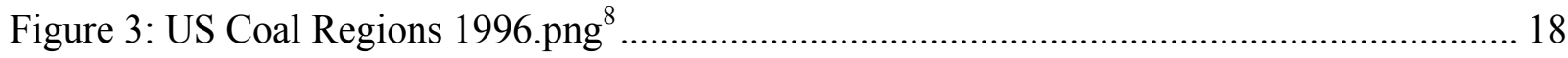

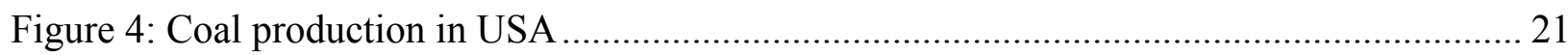

Figure 5: Different grades of Coal Production in USA .................................................... 22

Figure 6: Screen shot of the United States map showing different states................................ 35

Figure 7: Screen shot of the United States map showing counties of different states ................ 36

Figure 8: Counties of Bituminous coal rank in United States. ............................................. 38

Figure 9: Counties whose total production is more than 10,000 Million short tons (2008) ......... 39

Figure 10: States with Longwall Productivity is greater than 5 ......................................... 40

Figure 11: Sizes of the coal pillar at Different depths and Mining Heights ............................. 45

Figure 12: Relationship between Coefficient A and Mining Height (m) ............................... 47

Figure 13: Relationship between Coefficient B and Mining Height (m).............................. 48

Figure 14: Recovery Ratios for Various Mining Height (m) and Depth (h) ........................... 49

Figure 15: Base Capital and Annual Operating Costs of a Mine Ventilation System................. 53

Figure 16: Gas Content in Major US Coal Seams ….................................................... 55

Figure 17: Correction Factors for Required Ventilation Air Quantity ..................................... 57 
Figure 18: Graph showing the percentage of Ventilation costs to Total costs for different coal

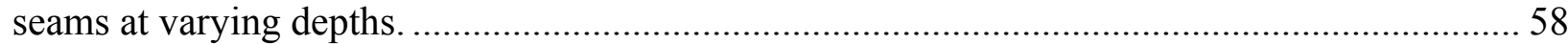




\section{List of Tables}

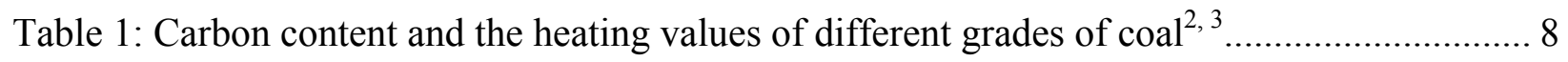

Table 2: Rank and location of different coal seams throughout United States.......................... 19

Table 3: Derived Coefficients A and B for the Power Function in Pillar Size Design with ........ 44

Table 4: Results of the regression studied for the coefficients A and B in the power function ... 46

Table 5: Determined Regression Coefficients for the Selected Coal Seams ............................ 56

Table 6: Coefficients for Correction Factor for the Selected Coal Seams............................... 57

Table 7: Average sale price of coal by state and coal rank, 2008....................................... 63

Table 8: Coal Production and Number of Mines by State, County and Mine Type................... 65

Table 9: Coal Production by State and Mine Type........................................................... 76

Table 10: Coal Production and Number of Mines by State and Coal Rank ............................ 78

Table 11: Recoverable Coal reserves and Average Percentage at producing mines by State ...... 80 


\section{Introduction}

Coal has played a significant role in the industrialization of the many major countries in the world. It is estimated that there are about 847 billion tons of proved coal reserves worldwide. It still supplies about $25 \%$ of the world energy. Coal has many important uses worldwide. The most significant uses are in electricity generation, steel production, cement manufacturing and as a liquid fuel. Around 5.8 billion tons of hard coal were used worldwide last year (2008) and 953 million tons of brown coal. Since 2000, global coal consumption has grown faster than any other fuel. The five largest coal users - USA, China, India, Japan and Russia account for $72 \%$ of total global coal use (World Coal Institute, 2009).

Coal has been an energy source for hundreds of years in the United States. Many envision a future in which coal continues to play a predominant role in the nation's diverse energy supply. It helped to provide basic needs of energy for domestic heating and cooking to transportation for people, products and raw materials to energy for industrial applications and electricity generation. America's economic progress historically linked to the use of coal from its abundant coal resources.

The estimation of the current coal reserves provides more accurate information of how much of the total US coal resource database is actually available for extraction in the coming years. The earlier studies have already confirmed that the economically recoverable resources are considerably less than that of the total resource database and it is required that more comprehensive assessment of the reserves should be done in order to extract coal economically. 
More studies are encouraged on the study of characteristics of coal, especially the depth of mining and the quality of coal to calculate the recoverability and feasibility of extraction.

The amount of recoverable coal reserves mainly depends on the geological formations and quality of the coal seams, future development of mining technology and the extraction costs. The objective of the research proposed by NETL is to design a financial model to estimate the cost of mining coal based on the technology chosen by geological conditions. In these efforts, CMU and WVU have evaluated the costs of extracting coal from myriad coal regions by developing a model. A cooperative research has been carried out by Carnegie Mellon University and West Virginia University to estimate different parameters for designing the model. In this aspect the contribution of West Virginia University in this study is to provide some of the works to enhance the coal reserve model. The recovery ratio estimation, the ventilation costs are included in the model and these works are contributed by WVU. The flow sheet in the next page explains the various inputs of the coal reserve model and the contributions of WVU in this project to calculate the cost per extracting each ton of coal.

The Department of Energy (DOE) has enabled the continued and potentially expanded use of nations secure domestic coal resources through the deployment of efficient generation technologies by eliminating environmental issues which act as barriers for coal utilization. 
Flow sheet showing various inputs for the Coal Reserve Model for calculating the cost of extracting ton of coal mined.

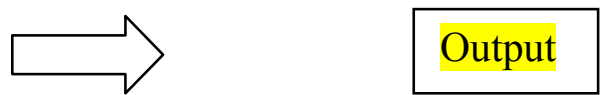

\section{Coal Reserve Model}

\section{Cost per ton of coal}

Input for the model
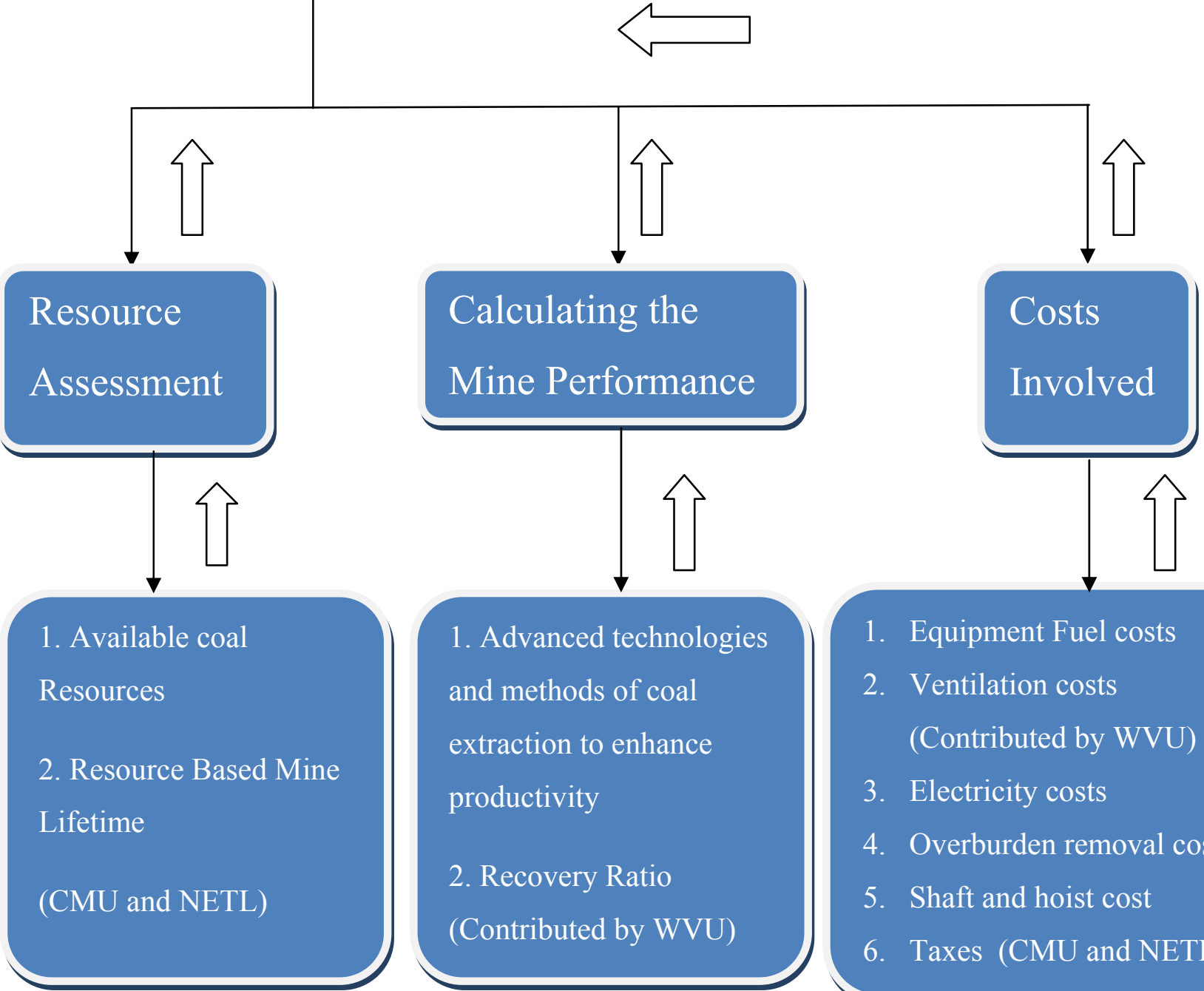

1. Equipment Fuel costs

2. Ventilation costs

(Contributed by WVU)

3. Electricity costs

4. Overburden removal costs

5. Shaft and hoist cost

6. Taxes (CMU and NETL) 


\section{Objective}

The main purpose of the project undertaken by National Energy Technology Laboratory (NETL) is to estimate the cost to extract coal from different US coal regions. The extraction costs are calculated as a function of geological characteristics and technology performance. This methodology mainly comprises performing a resource assessment on the available quantity of coal and its geological characteristics and then calculating the mining costs as a function of coal depth and thickness. Multiple calculations are employed to estimate the costs to underground or surface mine resource. The costs are found on a process based model that represents the unit operations of expected equipment to be used in these mining systems, and expected capital and operating costs for these methods, including salaries and taxes.

The scope of this project includes developing and demonstrating long-term coal supply associated with future scenarios of extraction technology and mine operations, developing regional cost curves, assessing regional coal resource availability and quality, and evaluating technologies and practices to minimize environmental impacts from mining and incorporating them into the estimation of coal mining costs. This work assesses the implications of continued coal use, as resources are consumed, and mining is undertaken under more challenging conditions than those that exist today. The analysis will evaluate the cost of mining coal in consideration of more advanced technologies and techniques to mitigate environmental impacts that may arise from extraction in the future. 
This thesis is related to the description of the characteristics of the United States coal reserves and designing of a coal resource database to identify different grades and properties of the coal available throughout the country using ARC GIS software. A set of databases are designed for describing different statistics of coal throughout the country and are incorporated into the software to identify the data directly on the United States map.

Analysis of these resources implied the continuous use of coal as the resources are consumed and mining is undertaken under more challenging conditions than those of today. With the extinction of the shallow deposits in this country, the increase in demand of coal led to deep seam mining. In order to face some challenging issues with increase in depth, the recovery ratio of extraction of coal is estimated to find the feasibility of extraction of a particular reserve. The complete extraction of the coal from underground is possible only when we have a very good idea on the nature of the reserve and the type of mining method. The recovery ratio of extraction of these coal resources at various depths and mining heights is calculated by designing suitable pillars for Room and Pillar mining method to prevent underground mine structural failures and surface subsidence. The pillar size is determined to estimate the recovery ratio using regression analysis.

This analysis also involves the study of cost of mining coal under challenging conditions. The most economic method of extraction mainly depends on the depth, thickness, geology of the coal seam and environmental factors. The ventilation costs which are substantially increased these days due to increase in the electricity costs are calculated for different coal seams at various depths. The methods used in SME hand book are used as base methods for calculation 
and are further adjusted by coal rank and depth. Because of the differences in coal seams and depths there is considerable change in the gas content in a ton of the mined coal and thus the required ventilation air quantity changes. It has been demonstrated by studies that the gas content in coal is a function of the coal rank and mining depth considering the gas emission is proportional to the gas content. Thus, the required ventilation air quantity also depends on the coal rank and the mining depth. 


\section{Literature Overview}

\subsection{Coal}

Coal is a fossil fuel which is formed from the partial decomposition of decaying animal and plant matter. It is created over millions of years under intense pressure from the layers of the rock and other sediments. The rank of coal is classified according to its heating value, fixed carbon and volatile matter content and also its caking properties during combustion. Based on these factors the rank of coal is classified into four categories.

$>$ Anthracite is a jet black coal with high heating value and is considered as the highest quality of coal.

$>$ Bituminous which is softer black and has somewhat low fuel value. This is the most common commercially mined grade of coal in the country.

> Sub-bituminous coal which is dull black or slightly brownish and it has a lower heating value.

Lignite which is brownish black in color and is considered as the lowest of the all commercial grades. This grade of coal is usually mined where no other low cost fuels are available. 
Table 1: Carbon content and the heating values of different grades of coal ( EIA and ABA, 2009)

\begin{tabular}{|c|c|c|}
\hline Coal Rank & Carbon Content \% & Heating Value (in BTUs per pound) \\
\hline Anthracite & $86-97 \%$ & Nearly 15,000 \\
\hline Bituminous & $45-86 \%$ & 10,500 to 15,500 \\
\hline Sub-bituminous & $35-45 \%$ & 8,300 to 13,000 \\
\hline Lignite & $25-35 \%$ & 4000 to 8,300 \\
\hline
\end{tabular}

\subsection{Distribution of Coal Reserves in United States}

Coal is the most abundant fossil fuel in United States. It has got the biggest supply of coal reserves in the world. Of the total world's coal reserve $27 \%$ exist in United States (i.e. 249 billion tons). Its abundance led to its major use for electricity generation, rails, and fueling factories. It is known that the coal production has been increased by $70 \%$ since 1970 . Nine out of every 10 tons of coal mined in United States today is used for electricity generation and about 56 $\%$ of the electricity used is generated from coal (American Coal Foundation, 2009).

Coal will continue to serve us in the forth coming years at the same rate as today as it is more abundant and cost effective than oil and natural gas. As per the current use it is known that the supplies are good enough for more 300 years. 
In Mining terminology, the resources are defined as the deposits of coal which occur in the Earth's crust that are economic in extraction and that are currently or may become feasible. (Coal Resource Classification System of the US Bureau of Mines and US Geological Survey) Resources are classified into different types. Some of them are explained below (Coal Reserves Data, EIA, 2009):

\section{Measured Resources:}

The measured resources are defined as those, where the rank and quality estimation is done from a high degree of geologic assurance from sample analysis and measurements from a closely spaced and geologically well know sample sites. Under the USGS criteria, the points of observation are not greater than half mile apart and the measured coal is projected to extend as a $1 / 4$ mile wide belt from the outcrop of observation.

\section{Indicated Resources:}

Indicated resources are those where the estimates of rank, quality and quantity are computed to a moderate degree of geologic assurance, partly from sample analyses and measurements and partly from reasonable geologic projections. Under the USGS criteria, the points of observation are from $1 / 2$ to $1 \frac{1}{2}$ miles apart. Indicated coal is projected to extend as a $1 / 2$ mile wide belt that lies more than $1 / 4$ mile from the outcrop or points of observation.

\section{Demonstrated resources:}

Demonstrated resources are one which are the sum of the measured resources and indicated resources. 


\section{Demonstrated reserve base (DRB):}

The Demonstrated reserve base is defined as the parts of identified resources that meet specified minimum physical and chemical criteria related to the current mining and production practices, including quality, depth, thickness, rank and distance from points of measurement. The "reserve base" is the in-place demonstrated resource from which reserves are estimated. This reserve base may contain resources which are economically recoverable within planning horizons that extend beyond those which assume proven technology and current economics.

\section{Inferred resources:}

Inferred resources are defined as the estimates of the lowest degree of geologic assurance in unexplored extensions of demonstrated resources for which estimates of the quality and size are based on geologic evidence and projection. The total quantity estimation is always based on good knowledge and geologic character of the bed and also the regions where few measurements are available and on assumed continuation from demonstrated coal for which there is geologic evidence. The points of measurement are from $1 \frac{1 / 2}{2}$ to 6 miles apart. Inferred coal is projected to extend as a $2 \frac{1}{4}$ mile wide belt that lies more than $3 / 4$ mile from the outcrop or points of observation or measurement. Inferred resources are not a part of the DRB. Minable refers to the coal that can be mined using present day mining technology under current restrictions, rules and regulations. 


\section{Reserve}

The term reserve refers the quantity which can be recoverable at a reasonable profit with the application of extraction technology available currently or in the nearby future.

The USGS conducts mappings and field studies to calculate the identified coal resources and makes an estimation of the undiscovered resources based on the available geologic information. The demonstrated reserve base is only part of the coal resource data and the EIA estimates are of the United States government coal resource assessment data. The coal reserves which are estimated by EIA are generally considered to be very limited for long term analysis as there is only limited data available to gather from the coal industry. So in-order to have detailed information on the coal reserves, it analyzes the DRB and also the measured, indicated, inferred resources. The estimated recoverable coal reserves are developed from DRB and also from the data on coal accessibility and recoverability. The identified and the inferred resources are estimated by USGS and are not included in DRB and the undiscovered resources estimated by USGS are included in the total resources classification.

The data shown in the figure 1 might be interrelated conceptually but in real time they cannot be maintained uniformly. The recoverable reserves at the working mines are included in the estimated recoverable reserves by EIA. As some of the data at mines may include reserves other than the one from the DRB and the EIA, the mine data EIA receives are not good enough to use for analysis. And the data from the active mines are more accurate and timely than detailed resource studies from which the estimated recoverable reserves are derived. In the figure the data of the active mines are more current than the DRB as the data was derived from more 
updated sources when the USGS compiled the total resources. As there is very limited planning as of now it is difficult to assume that the total resources of coal will be updated by USGS in the near future (Coal Reserves Data, EIA, 2009).

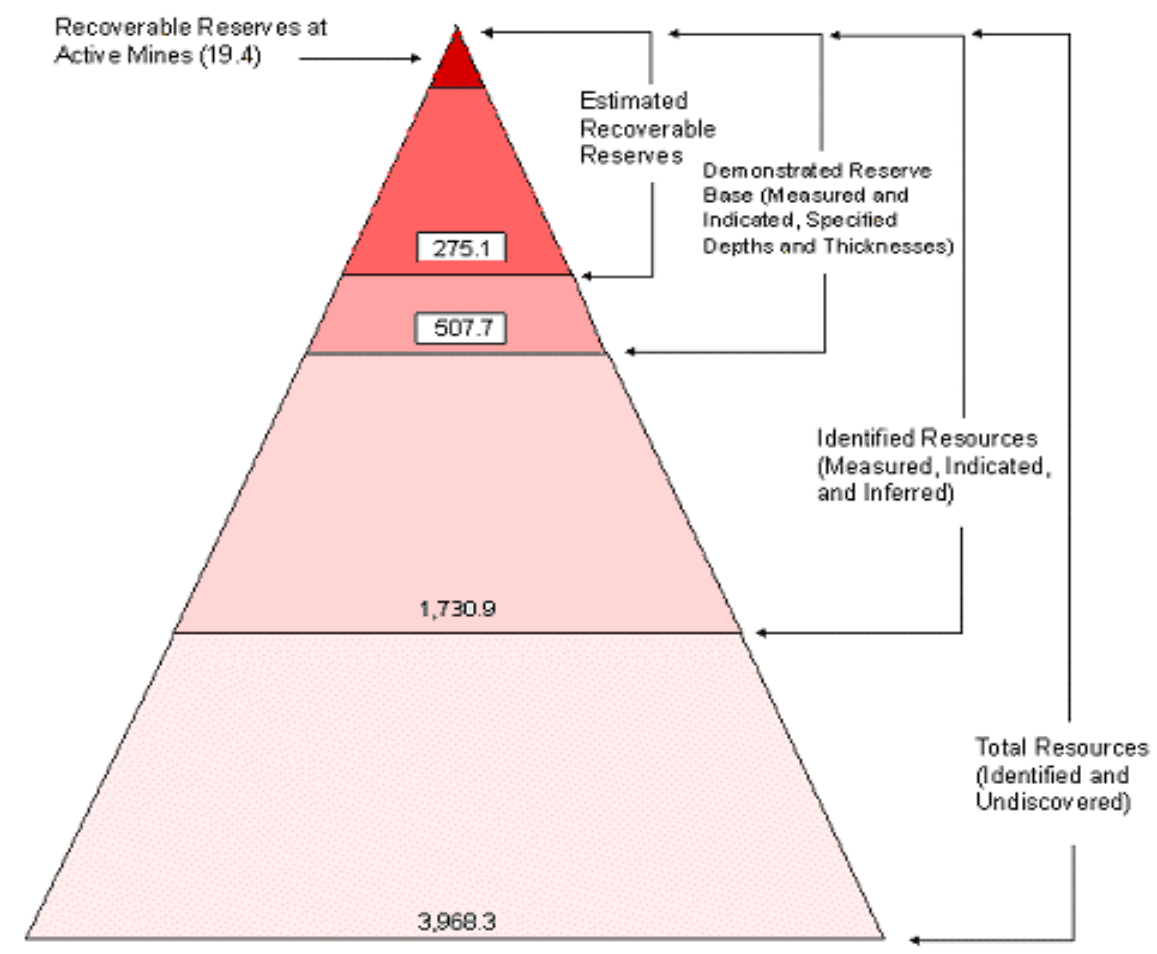

\section{Figure 1: Delineation of U.S. Coal Resources and Reserves ${ }^{5}$, EIA 1997}

(Unit: Billion short tons) (Source: U.S. Geological Survey in Coal Resources of the United States,

January 1, 1974.)

The above figure clearly defines the relationships of magnitude of the data and also the reliability among the coal resource data. The data of the reserves presented in figure 1 are in billion short tons. The topmost part of the above figure represents greater reliability of the data. It clearly 
indicates that the 19 billion short tons of recoverable reserves at active mines are part of the same body of resource data.

The figure 2 shown below shows the major coal bearing areas by states in United States. It shows the areas which contains the identified and undiscovered resources, occur primarily as tabular deposits or coal beds within the rocks in certain coal bearing areas and also the demonstrated reserve base (DRB).

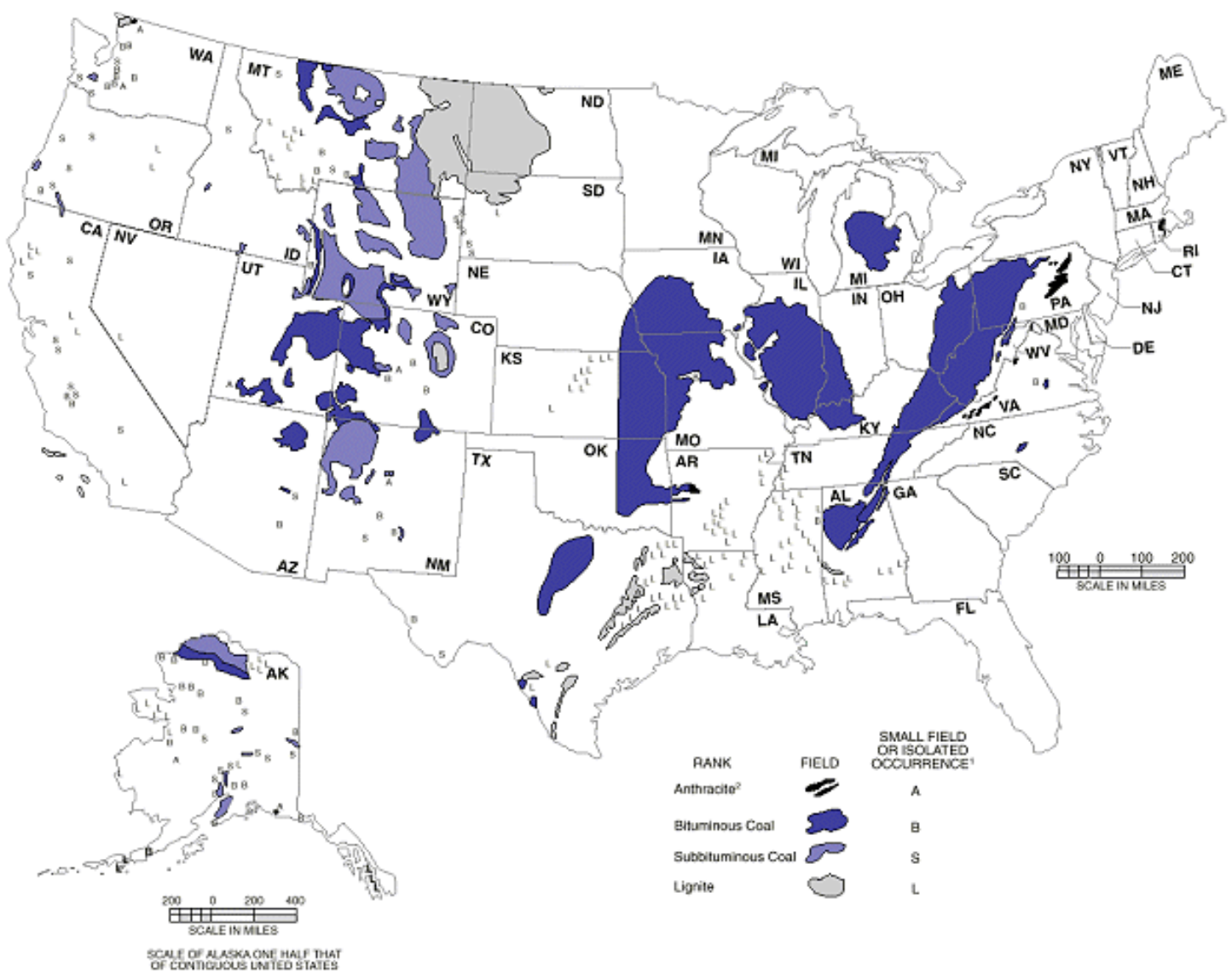

Figure 2: Coal-Bearing Areas of the United States ${ }^{5}$

Sources: (http://www.eia.doe.gov/cneaf/coal/reserves/chapter1.html\#fig1) 


\subsection{Mineable Coal seams in US and their Rank Information}

The coal reserves of United States are the largest of any country in the world. The recoverable coal reserves are found in 32 states. The ten states with the largest recoverable coal reserves contain approximately $89 \%$ of the total coal in the United States.

The USGS (United States Geological Survey) and the US Bureau of mines have initiated the coal availability and recoverability studies to evaluate the recoverable coal throughout the country. The USGS National Coal Resources Assessment used digital database and GIS for a national coal resource assessment and that is considered to be very important for the feasible extraction of coal in future. These databases contain very valuable information regarding the tonnage, rank, overburden, hydrology, mineability, coal bed methane occurrence etc.

The U.S. Geological Survey has divided the reserves in to seven provinces (US Coal Resource Database, 2009):

1) Eastern Province

2) Interior Province

3) Gulf Province

4) Northern Great Plains Province

5) Rocky Mountain Province

6) Pacific Coast Province

7) Alaskan Province 
These provinces are further sub-divided into regions, fields and districts and they are clearly represented in the figure 3.

\section{Eastern Province:}

The eastern province which is about 900 miles long and 200 miles wide majorly includes the anthracite regions of Pennsylvania and Rhode Island, the Atlantic coast region of middle Virginia and North Carolina and also the Appalachian basin which extends from Pennsylvania, Tennessee and Alabama. There are about 760 million short tons of anthracite in Eastern Pennsylvania in this province.

The Appalachian region is known to be the largest region of bituminous coal deposits in the United States. The southern part of this basin's coal is mainly of high volatile bituminous rank also with some medium and low bituminous rank. The northern part of this region has high volatile coal in the west to low volatile bituminous coal in the east. The central region coal varies from low volatile to high volatile bituminous in rank.

\section{Interior Province:}

The interior province consists of 3 major regions that include the northern region consisting of Michigan, the eastern region or the Illinois basin and the western region.

The Illinois basin consists of Illinois, southern Indiana and the western Kentucky. And the western region consists of Iowa, Missouri, Nebraska, Kansas, Oklahoma, Arkansas and western Texas. 
This region has vast number of reserves in Illinois and western Kentucky. The coal in this province is mainly bituminous in rank and tends to be lower in rank and higher in sulfur than the Eastern Province bituminous coals.

\section{Gulf Province}

The Mississippi region in the east and the Texas region in the west are the main regions of the gulf province. These coals are basically lignite in rank and are considered to be the lowest rank coals in the United States which have moisture content up to $40 \%$.

\section{Northern Great Plains Province}

The lignite deposits in North Dakota, South Dakota and Eastern Montana are part of the Northern Great Plains. These are considered to be the largest lignite deposits in the world and are present in the Fort Union Region. The sub-bituminous fields of the northern and eastern Montana and northern Wyoming are also a part of the Northern Great Plains Province. The states of Wyoming and Montana are considered to be the states with largest recoverable reserves in United States. The reserves of the Wyoming state are shared by the Northern Great Plains and the Rocky Mountain Province. The Northern Great Plains contains subbituminous coal from the Powder River basin. The Powder River basin coals contain $1 \%$ sulphur with low ash content (3-10\%) and are used as power station fuels. 


\section{Rocky Mountain Province}

The mountainous districts of Montana, Wyoming, Utah, Colorado and New Mexico are the major coal regions of the Rocky Mountain province. These coals rank varies from lignite to anthracite. The coals from the areas of Wyoming, primarily from the Green River, Hanna and Hanna Fork are the most prominent fields of this province and are sub-bituminous in rank.

\section{Pacific Coast Province}

The deposits in Washington, Oregon and the California are of the Pacific Coast Province. These coals are very limited and scattered and their rank range from lignite to anthracite.

\section{Alaskan Province}

The Alaskan province also contains coal in different regions and their rank ranges from lignite to bituminous with little anthracite. The coal available in this area is considered to be $15 \%$ bituminous and $85 \%$ sub-bituminous and lignite. This province is not shown in the figure. 

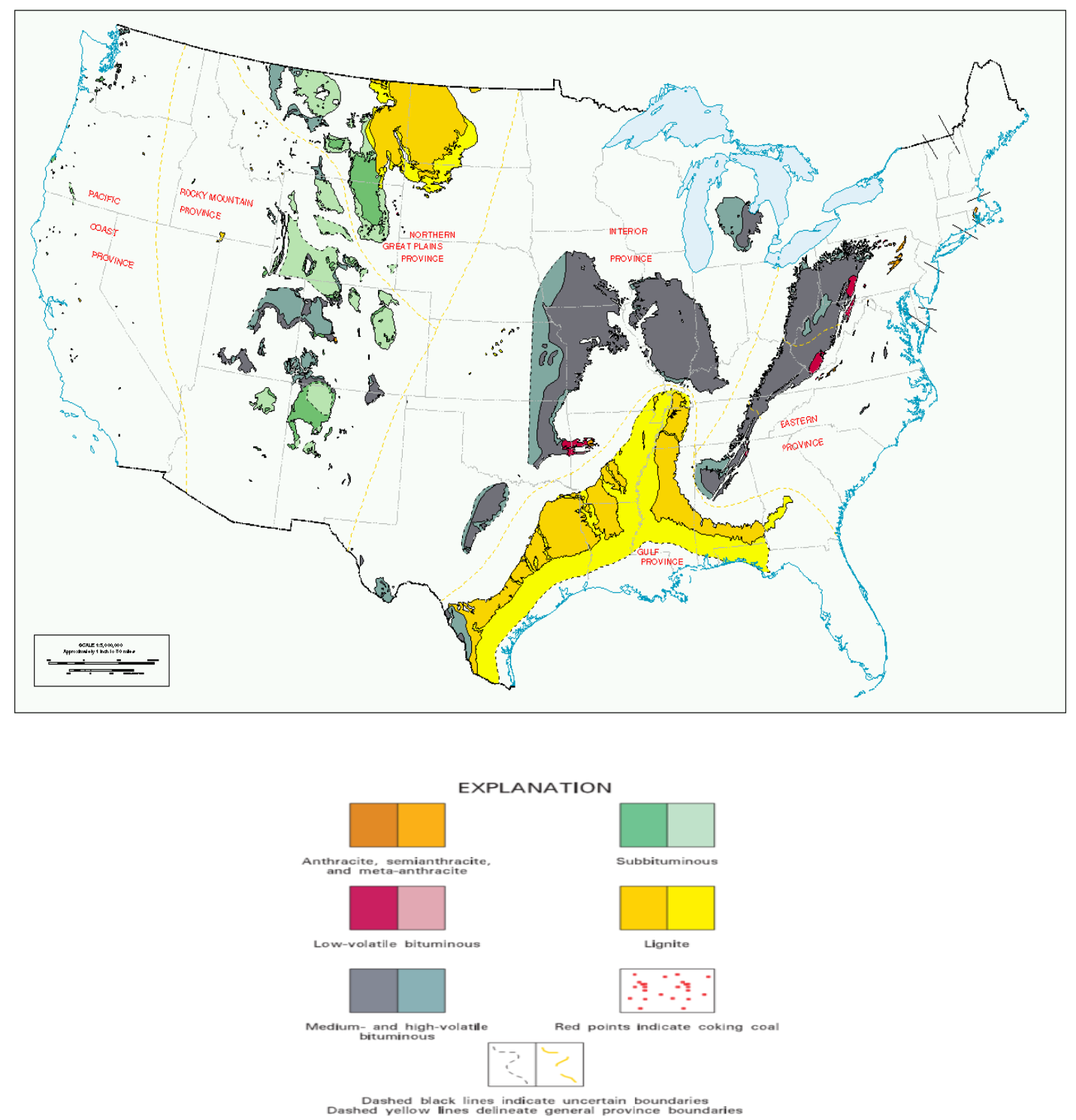

Figure 3: US Coal Regions7

(Source: http://en.wikipedia.org/wiki/File:Us coal_regions 1996.png)

The deep color represents the areas of coal reserves of good commercial value. The minimum thicknesses included are 14 inches for anthracite and bituminous coal and 30 inches for sub-bituminous coal and lignite. The light color represents the doubtful value for coal. This is 
further divided into three regions: (1) areas containing thin or irregular beds, which have very less or no value but thick enough to mine, (2) the areas with poor quality of coal (3) areas where there is no enough information on the thickness and quality of the coal beds. The Alaskan province is not shown in the above figure.

Table 2: Rank and location of different coal seams throughout United States

\begin{tabular}{|c|c|c|}
\hline Region & Location & Coal Rank \\
\hline Eastern & $\begin{array}{l}\text { Pennsylvania and Rhode } \\
\text { Island, the Atlantic Coast } \\
\text { region of middle Virginia } \\
\text { and North Carolina }\end{array}$ & $\begin{array}{l}\text { Some of the coal deposits are anthracite and this } \\
\text { region contains largest deposits of Bituminous coal } \\
\text { in United States. Northern region of the } \\
\text { Appalachian basin the coal rank ranges from high } \\
\text { volatile bituminous coal. }\end{array}$ \\
\hline Interior & $\begin{array}{l}\text { Illinois and } \\
\text { Kentucky }\end{array}$ & $\begin{array}{l}\text { The coal in this region is mainly bituminous in } \\
\text { rank and tends to be lower in rank and higher in } \\
\text { sulphur than the Eastern Province bituminous } \\
\text { coals. }\end{array}$ \\
\hline Gulf & $\begin{array}{l}\text { Mississippi, Louisiana and } \\
\text { Texas }\end{array}$ & $\begin{array}{l}\text { The coal in these regions is lowest rank coals in the } \\
\text { United states having moisture contents up to } 40 \% \text {. }\end{array}$ \\
\hline $\begin{array}{l}\text { Northern } \\
\text { Great }\end{array}$ & $\begin{array}{l}\text { Part of Wyoming, North } \\
\text { Dakota, South Dakota, }\end{array}$ & $\begin{array}{l}\text { Sub-bituminous fields in Northern and Eastern } \\
\text { Montana and Northern Wyoming. And lignite }\end{array}$ \\
\hline
\end{tabular}




\begin{tabular}{|l|l|l|}
\hline plains & Eastern Montana & deposits are contained in the Fort Union Region \\
& and are the largest lignite deposits in the world. \\
\hline Rocky & Montana, Wyoming, Utah, & The coals from Wyoming primarily from the Green \\
Mountain & Colorado, and New Mexico. & River, Hanna Fork coal Fields are sub Bituminous. \\
\hline Coast & California & These coals range from lignite to Anthracite \\
\hline
\end{tabular}

\subsection{Coal Production in USA}

Coal production in USA grew steadily over years. In 1950 the coal was consumed by various sectors like industrial, residential and commercial, metallurgical coke ovens, electric power and transportation. These sectors distributed the consumption evenly with 5 to $25 \%$ of the total consumption. The use of coal for rail and water transportation has been declined since the Second World War however with the growth after the war; the demand of coal grew rapidly with increased electricity generation. From the graph we can see that the coal production in 1950 was 560 Million Short Tons and in 2003 was 1.07 Billion Short Tons. There has been an average increase of 1.2 per every year since 1950 . Presently the coal demand is majorly controlled by the electric power sector which accounts for $90 \%$ of the consumption compared to the $19 \%$ it represented in 1950. With the increase in the demand for electricity, the demand for coal generation also increased and that resulted in increased coal production(Coal Production in US, 2006). The figure 4 explains the rate coal production in United States over years. 


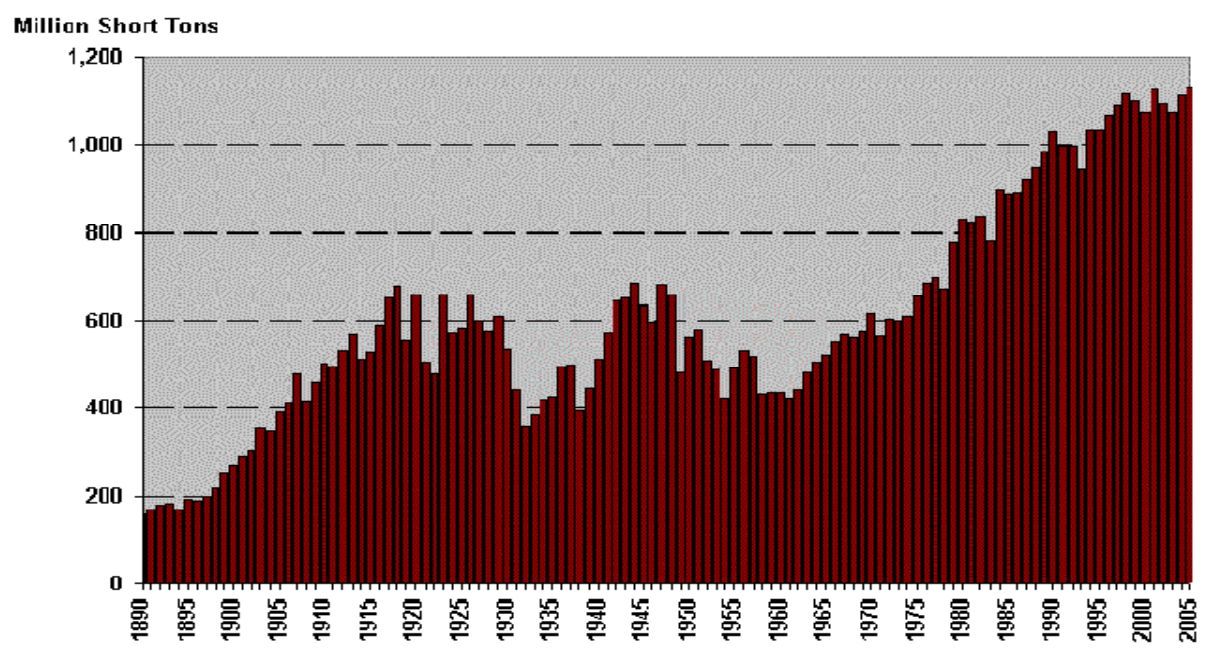

Figure 4: Coal production in USA 1890-2005 ${ }^{8}$

(Source: Coal Production in the United States, Energy Information Administration, Oct 2006)

As the coal production in United States is increasing steadily it is clear that the high quality coal is nearing its end. From the graph we can see that the anthracite production has been declining steadily since 1950 and the bituminous coal is also declining since 1990 . Even though the anthracite and bituminous coal productions are declining the total production is still increasing about 20 MT per year since 1960. Since the past few years the production of the low quality sub-bituminous and low quality lignite has been increasing substantially. This is majorly responsible for the increase in the total production of the coal (Energy Watch Group, 2007). The figure 5 below represents the production rates of different grades of coal in United States over years. 


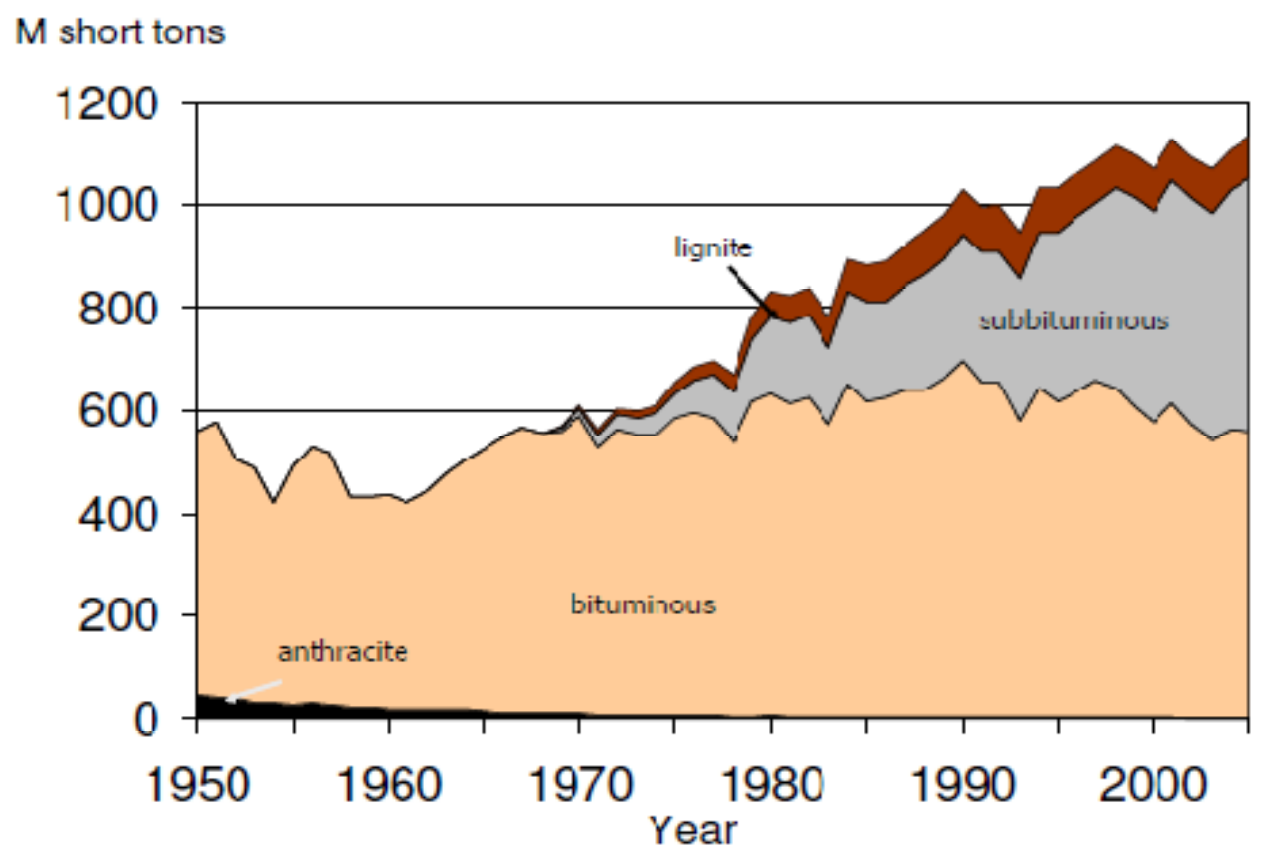

Figure 5: Different grades of Coal Production in USA ${ }^{9}$

(Source: Coal: Resources and Future Production, Energy Watch Group, March 2007)

\subsection{Mining methods}

Mining is the economical extraction of the valuable minerals from the ore body from the Earth's crust. The most economic method of extraction basically depends on the depth and the geology of the coal seam. The coal mining processes are differentiated by surface and underground extraction. Most of the seams are considered as too deep for surface mining and require underground mining. Based on the characteristics of the coal seams different methods are employed for extraction. 
The selection of mining method is mainly dependent on the geology of the deposit and the extent of ground support needed to make the method productive and safe. The two major methods of extraction involved in underground mining of coal are:

1. Room and Pillar Mining (Continuous Mining): This method is oldest method which is applied to horizontal or nearly horizontal deposits and is used in both coal and non-coal mining. This method is considered to be very cheap, easily mechanized, highly productive and is also simple in design. Compared to longwall mining this method is flexible and does not require high capital and development costs.

Room and Pillar method of mining is an open stoping method and is applied in a competent rock where the roof is primarily supported by the pillars. The coal is extracted from the rectangular or square shaped pillars driven into the coal seam leaving parts of coal between the entries to support the roof. Continuous miners are used for extraction in this method. The dimensions of the pillars formed depend on many design factors like the strength of the ore, the thickness of the deposit, depth of the mining etc. our main goal is extract maximum percentage of coal from the ore body under safe working conditions. The left out coal after the ore extraction is considered non recoverable but in some cases it can be recovered by backfilling which is one of the limiting factors for this method especially when mining at greater depths. Generally the pillars are recovered by retreat mining which allows the roof to cave and thus relieves the stress and reduce bumps.

Even though the advance rates are much higher in longwall method all except very minor faults should be avoided and with this large areas of reserve are not mineable 
and give much lower recovery rate than retreat Room and Pillar mining method which is highly flexible. (Hartman, H.L., and Mutmansky, J.M., 2002)

2. Longwall mining: This method of mining is employed where the deposits are tabular, horizontal and having a thickness from 3 to $8 \mathrm{ft}$, and dipping at less than $12^{0}$, and lying at depths up to $3000 \mathrm{ft}$ or more. In this method a system of props are employed to support the roof and the working areas. These supports advance with the face and are responsible for the caving of the roof in the mined out area. The over lying deposits should be thin bedded, and cave freely in order to implement this method. Also the floor should be sufficient strong enough to support the prop loads.

In this method of mining the panel layout is very simple and provides good ventilation and always safe to work under the supported roof. This is considered to be much safer than the room and pillar method and complies easily with current US laws. As the coal is extracted completely with leaving lesser residual pillars with full caving the coal recovery is higher and the surface subsidence is uniform and complete.

In United States retreating longwall is generally followed. The entries on the both sides of the panel are called head gate and tail gate where head gate is used for the intake air and coal transportation and the tail gate is for the return air. The coal at the face is cut by a shearer and is loaded on the armored flexible conveyor (AFC) and is then transferred to the stage loader and then to belt conveyor. A series of powered supports are used to support the roof and these supports along with the AFC advance with the face. This 
method of roof control is called as roof caving method. The area behind the supports after the face advances is called as gob. (Hartman, H.L., and Mutmansky, J.M., 2002)

\subsection{Mining costs}

The success of a mining company mainly depends on the cost of the product and the sales realization. This means that the costs for every mining operation have to be pre-calculated in order to have a good idea of the costs and prices. This is considered to be a very difficult task as it involves lot of variables which vary with different conditions. The wide variety use of equipment and variation in the working conditions makes very complex to get the results very accurately. Mining costs are mainly dependent on the nature of the deposit and the type of extraction. It is not like we use a lowest cost mining method to extract the ore but we should employ a method which result the lowest cost per unit of product when mining costs and treatment are considered together. Ventilation is the most useful and mostly used process underground because of the extent of its demand and it might get complicated and costly when the distance that air must travel from the surface to ventilation face is increased.

There are different kinds of costs involved in mining.

1. Capital costs: The capital costs mainly include the cost of new equipment, taxes, wages etc.

2. Operating costs: Operating costs are calculated according once the method of extraction and the output rate have been established. These costs mainly include things like production, labor, materials, supplies, maintenance, drilling, blasting, loading etc. The 
labor costs are estimated by establishing the crews needed to operate a mine production section.

Many of the mining companies claim to have model that estimate the mine costs. The mine cost analysis which is very expensive seems to be done on individual computer models. The major research organizations disclose sufficient details of their models and operational variables to validate their cost analysis, and usually provide their models in electronic for purchases. The cost estimates are always dependent on the complete technical information of the mine.

\subsection{Previous Cost Models}

Many companies would like to know what would be the capital cost and the operating cost before starting the actual production. As no one can estimate the exact figure as it is very difficult, it is very important the how accurate the model can predict the cost of extraction. Some of the cost estimation models are derived before and they are explained below.

\section{US Bureau of Mines Cost Estimating System}

One of the best mine cost modeling systems in US is US Bureau of Mines Cost Estimating System or CES which was developed in the USBM's Field Operations Centers and by well known mining Engineering consultants. Cost Estimation System (CES) is developed for estimating the capital and operating costs for development and operations at mineral properties. The system can be customized according to the availability of engineering and other operating data. 
The cost equations in CES are based on individual cost estimates for a variety of capacities, based on current technology applicable to each section. Regression analysis is then applied to the individual costs at the various capacities or size ranges using actual mine operating data to produce the resulting cost equations. Each section of CES has capital and operating costs appropriate for the specific unit process, plus descriptive text planning what aspects of a typical operation are included in the cost equations for that section. Capital and operating costs are usually expressed in three equations: labor, supply, and equipment.

\section{SME Handbook}

According to the SME handbook estimation of costs is being done in a different way. The accuracy of the estimation of capital costs and operating costs depends on the quality of the technical assessment and knowledge of expected mining and mineral processing conditions. Accurate operating costs are estimated from the quantities and unit costs of all components. The capital costs and operating costs of a mining project will be influenced by many factors that must be assessed before costs can be estimated for a preliminary feasibility study. (Mine Cost Models, USBM, 2009) 


\section{Characteristics of US Coal Reserves}

The United States coal reserves are considered to be larger than the present natural gas and oil resources. These reserves are identified throughout the country by Energy Information Administration (EIA) and the remaining tons of coal are updated every year in the Demonstrated Reserve Base (DRB). As the data quality of the coal resources is poor, EIA has started updating the records through coal reserve database program (CRDB). In this program the states are encouraged to revise the coal reserves in their respective states and collect the data and are further updated in the Demonstrated Reserve Base by EIA. The estimation of the current reserves provides information regarding the actual amount of coal that is actually available for extraction in future. (Luppens, J.A., et al., 2009)

This data collected gives a comprehensive view of the coal resources based on the past and current coal production and makes an analysis to provide an outlook on the possible coal production in the coming decades. The EIA has taken initiative and proposed a new project in 2008 to incorporate the existing reserves data into a geographic information system (GIS) based program. This includes the current and the USGS data.

In this regard, my application of the ARC GIS software is to incorporate the available coal resource data taken from the EIA and USGS into the software and create mappings to view different characteristics and availability of the coal resources throughout the country. The databases are designed to represent several things like the total amount of recoverable coal 
reserves, production from surface and underground, number of mines in each state, sale price of coal, measured and indicated coal reserves in different regions throughout the country.

\subsection{ARC GIS 9.3}

\section{Introduction}

GIS is one of the most powerful technologies that focuses on integrating the data from multiple sources and creates cross cutting environment for collaboration. It is also attractive to all people as it is intuitive and cognitive. It combines a strong analytic and modeling framework that is rooted in the science of geography.

Basically there are three fundamental views in GIS. They are:

1. Geo-database View: The geographic information is basically managed by GIS and it is considered as a spatial base containing different datasets that represent geographic information. The datasets are like map layers which are geographically referenced to overlay on to the earth's surface.

2. Map View: GIS is a set of intelligent maps and views where different features and feature relationships are shown. Various map vies of the underlying geographic information can be constructed and used as "windows into the geographic database" to support query, analysis, and editing of geographic information. A series of two dimensional or three dimensional map applications are provided in GIS for working with geologic information through these views. 
3. Geo-processing View: GIS is a set of information transformation tools that derive new information from existing datasets. These geo-processing functions take information from existing datasets, apply analytic functions, and write results into new derived datasets.

In this study Arc Map is used for incorporating the database into the software and views the results.

\section{ARC MAP}

ARC MAP is the central application used in Arc GIS. The data sets which we take into consideration are being studied in this area. We can create and edit datasets and also create map layouts for printing in this area. The map represents the geographic information as a collection of layers and other elements in a map.

\section{Arc Map documents}

Once we create the map using this application it is saved with filename extension .mxd on the disk. The map documents contain display properties of the geographic information we work within the map like the map layers, data frames etc.

\section{Views in Arc Map}

The map contents in an Arc Map are displayed in one of the two views below. Each view makes us to look and interact with the map in a specific way:

- Data view

- Layout view 


\section{Tables}

Tables are generally made up of rows and columns and it is necessary that all rows should have the same columns. In GIS, the rows are termed as records and the columns as fields. Each field can store a specific type of data like a number or a text. In our databases the fields are the rank, tonnage, depth, production, productivity etc and the records are the states and the counties. The databases used in this work are made in the form of tables for simple usage. The records of one table can be associated to another table in this software. This can be done by using joins or creating relationship classes in our geo-database.

\section{Joins}

The application of Joins is generally used whenever we need to append the fields of one table to those of another through an attribute or field which is common in both the tables. We can define the join based on the attributes or a pre-defined geo-database relationship. Number of tables can be joined to a single table. When a join table is removed, all the data from the tables which were joined after it is also removed, but the data from previously joined tables remain. We can add the tables from different sources to the Arc Map in the similar way as we add data to our map. The attributes of a layer on a map can be explored by opening its attribute table and find features with particular attributes. We can open multiple tables at a time in Arc Map. 


\section{Adding tables to a layout}

We can display the attributes tables to edit and make a selected appearance on the layout. We can select the rows which can be displayed on the layout by arranging the data in the table window beforehand.

\section{Identify function}

This function is primarily used for the identification of the attributes of the selected area. The data from the tables which is incorporated into the map can be viewed directly by using this function. We can edit the fields that are needed to display in this function.

\section{Select by attributes function}

This function is used for query building. As the name suggest "select by" indicates that we can select the desired set of results by developing a query and using it in the select by attributes function. In the query builder the number values should be given in single quotes.

\subsection{Sources for the Data}

The production and productivity data, recoverable reserves data, average mine sale price data are primarily obtained from the annual coal report tables 2008.

The measured and indicated reserves data is obtained from the US Coal Resources Database. The location, quality and several characteristics of coal are available in the database. The coal tonnage for a specific area like state or county is estimated and the rest of the 
characteristics are given in terms of USGS classification system. The published US coal resources estimates are organized by state, county, coal field, geologic age and formation, rank, thickness of coal, thickness of overburden and reliability of data.

\section{List of databases}

1. Average sale price of coal by state and coal rank (2008).

2. Coal production and number mines in different states at county and state level (2008).

3. Complete database of the recoverable coal reserves, estimated recoverable reserves and Demonstrated Reserve Base (DRB) by mining method (2008).

4. Recoverable coal reserves and the recovery percentage at producing mines 2008, 2007.

5. Underground coal production and productivity by state and mining method (2008).

6. USGS measured and indicated reserve database.

\subsection{Methodology}

The databases are primarily designed in Excel for simple usage. A different set of databases are taken as sources and used in this software to obtain the results. The datasets are obtained from the United States Geological Survey and the Energy Information Administration and are the main sources for the data used in this study. The datasets taken from the sources are defined in a used defined database form.

The USA maps at state level and county level are viewed by adding the .shp files into the arc map. The .shp files that are required for loading the maps are obtained from ESRI. We can change the color of the map to get the desired view. After adding those files, data the database 
tables which are designed in Excel are then added to the same layer. The attributes of the database defined can be viewed by right clicking on the database added and open.

It is required that the fips codes for the states and the counties in the designed databases are added as they are used as the primary key for incorporating the data into the map. The fips codes in the database tables are required to be entered in string format as they are in the text format in the shape file.

In order to incorporate this data on to the map, the database table should be joined to the shape file using fips code as the primary key. This can be done by right clicking on the shape file and got to joins and relates and then join. We have to select the field in that layer in which the join bases on and select the same field as they act as the primary keys and then click ok.

This adds the data present in the database table to the main table and they can be further viewed by using Identify function. The identify function which is indicated by letter "i" is located in the tool bar. All we need to do is click on the identify function and then click on the desired location to view the characteristics of that location. Using select by attributes function we can define different queries to view the selected data on the map. The data highlighted in the map represents the areas which satisfy the written command.

\subsection{Results}

The following views are some of the results obtained after incorporating the database elements into the software. The results are completely based on the input elements given in the databases. 
The figure 6 represents the screen shot of the map showing different states in United States in ARC MAP after loading the states shape file.

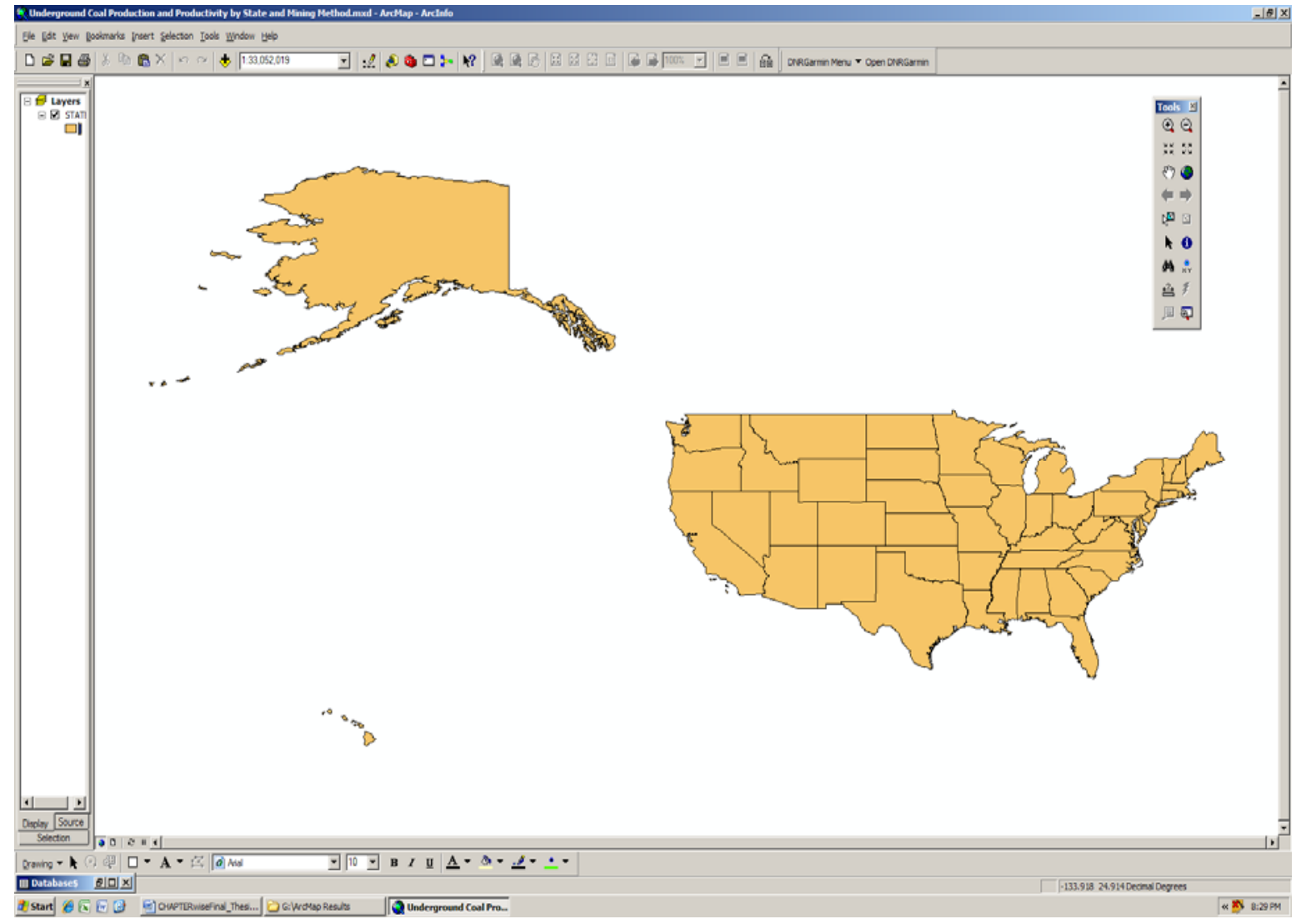

Figure 6: Screen shot of the United States map showing different states 
The figure 7 shows the screen shot of the map showing counties of different states throughout the United States.

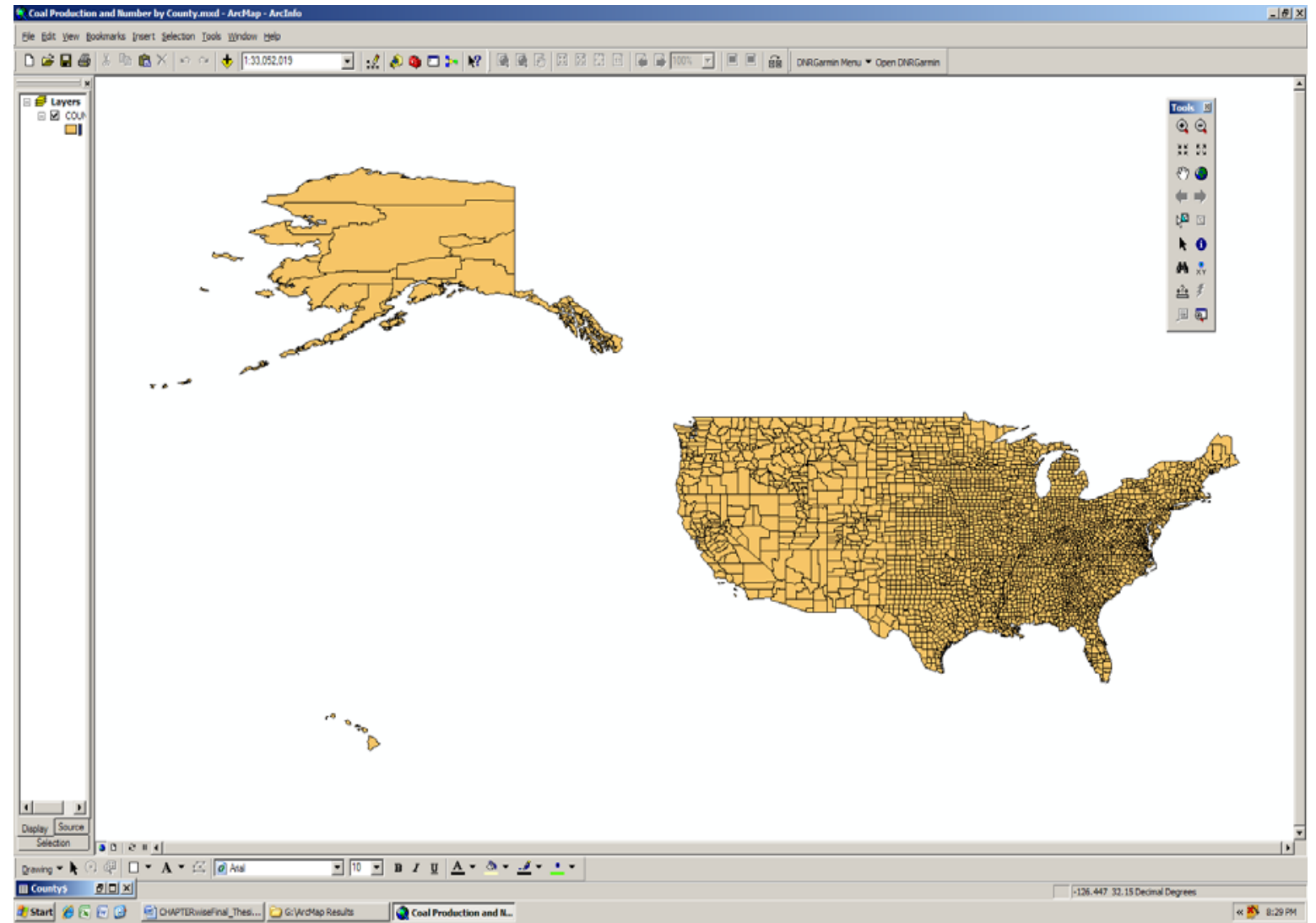

Figure 7: Screen shot of the United States map showing counties of different states

To view the areas where the bituminous coal throughout the United States at county level, we need to add the USGS measured and indicated reserves database table to the map and join with the shape file. In the select by attributes function we need to define the following query:

SELECT * FROM COUNTIES Database\$ WHERE “Database\$.Rank”=’BIT” 
After writing the query we need to verify whether there are any errors by clicking the "verify" button. After the expression is successfully verified click OK to view the result on the map. The characteristics data of a particular county can be further checked by using the identify function.

A screen shot of the view after successfully executing above defined query. The following figure represents the coal regions (counties) of United States where the measured and identified bituminous coal reserves are available.

\section{Query:}

“Database\$.Rank” =’BIT” 


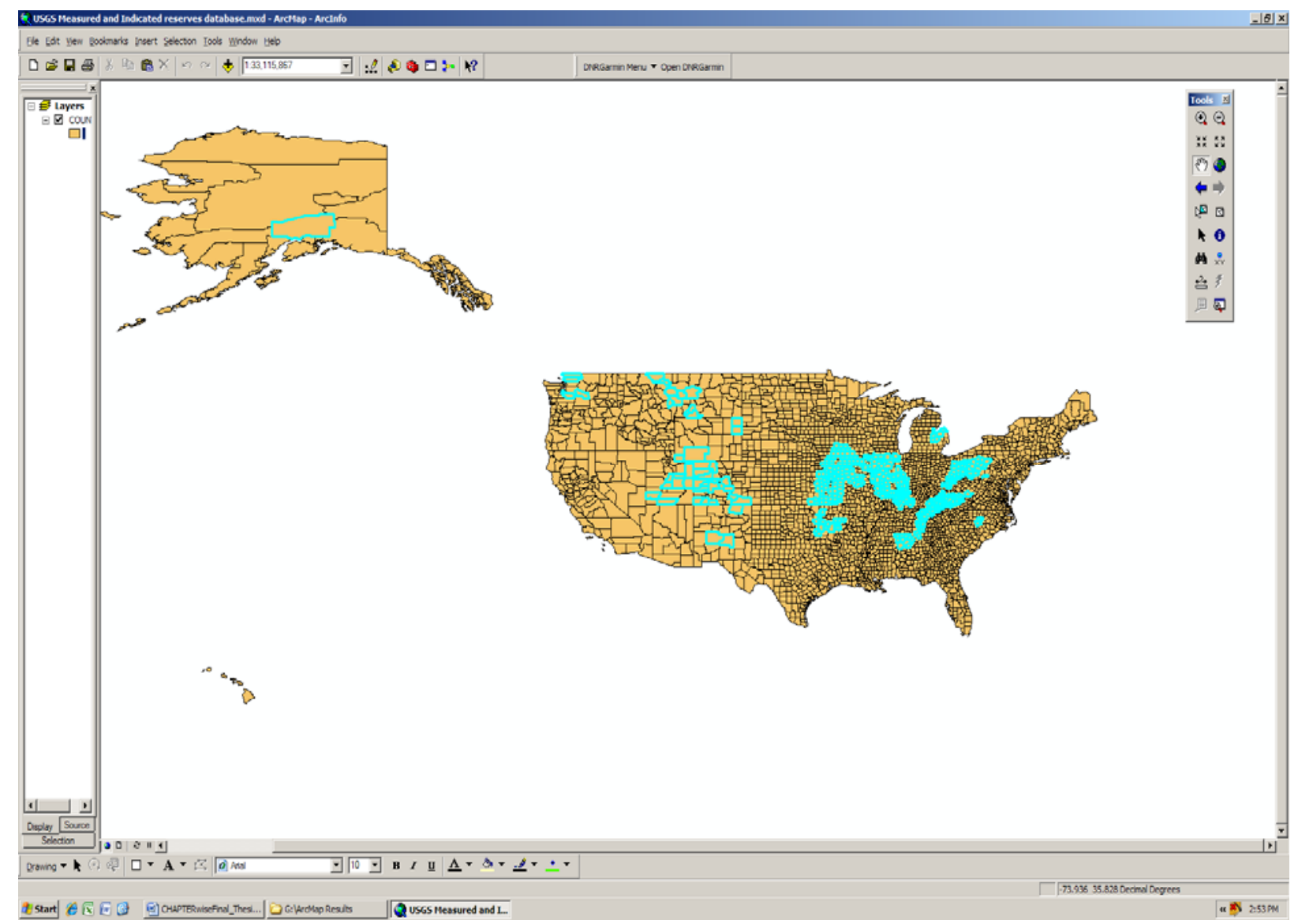

Figure 8: Counties of Bituminous coal rank in United States. 
The following screen shot shows the counties where the total production is more than 10,000 MST (2008).

\section{Query:}

“County\$.Total Production (in MST)” > 10000

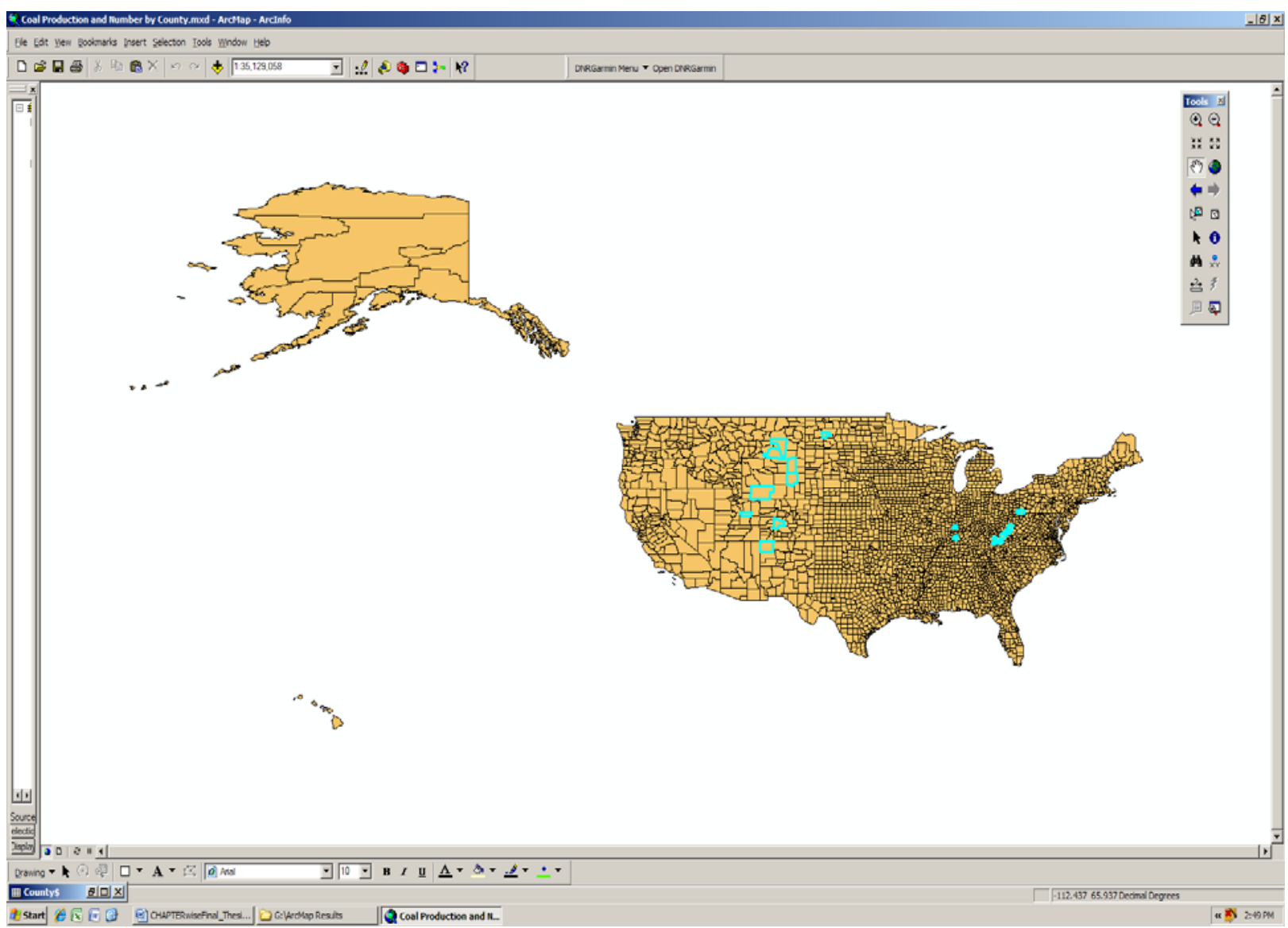

Figure 9: Counties whose total production is more than 10,000 Million short tons (2008) 
This figure 10 shows the states whose longwall productivity is greater than 5 .

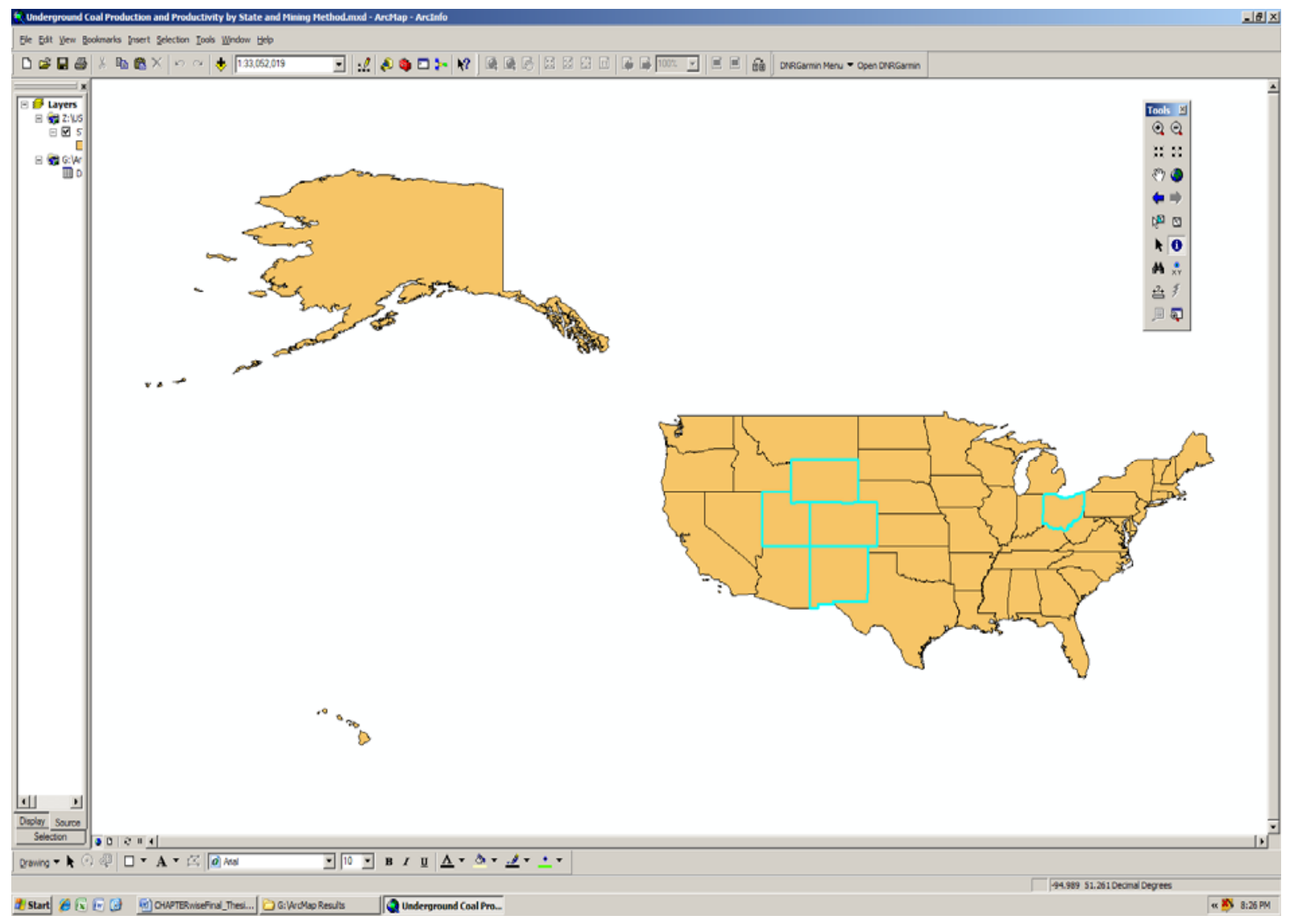

Figure 10: States with Longwall Productivity is greater than 5 


\section{Recovery Ratio}

Over recent years it has been observed that the reserve to production ratio has been falling. We are at a point at which the maximum coal production rate is reached and from here on now it is found that the rate of production will enter irreversible decline. So considering the extinction of these valuable fossil fuels it is necessary that we have to use them very efficiently. The reserves which are available now can be extended further by various developments like improving the exploration activities to find new reserves and implementation of advanced mining techniques which will allow the inaccessible reserves to be reached which improves the recovery ratio of extraction.

The recovery ratio of extraction of coal by underground mining varies a lot with the surface mining of coal. In underground mining, some portion of the coal is left as pillars to support the roof and this portion of coal is left out and cannot be recovered. In addition to this some amount of coal is lost with the geological disturbances like folding, faulting etc and this limits the recovery ratio. It's been a challenge for the engineers today to extract the maximum percentage of coal from the total recoverable reserves where the depth of mining is increasing gradually and the recovery ratio is decreasing.

The estimation of the recovery ratio of the pillars in room and pillar method of mining is made in this study. This is done by calculating the size of the pillar as a function of mining depth and mining height. One of the important aspects involved in room and pillar method is the design of the pillars. The ground control in this method is completely dependent on the pillar design. 
Many theories have been proposed and there has been a substantial progress in the design over years. (Mark, C., 2006)

\subsection{Pillar Design}

In order to have a good recovery ratio at a given mining condition using room and pillar method, the design of pillars should be properly done in order to prevent the underground mine structural failures and subsidence. This can be done by designing square pillars in a plan view. The size of the pillars is calculated as a function of coal depth and mining height so that it is easier to determine the size of the pillar at a desired depth.

The size (i.e., the side length, $\mathrm{W}, \mathrm{ft}$ ) of the pillar mainly depends on the in-situ strength of the coal $\left(\sigma_{\mathrm{i}}\right)$, the overburden depth, room width, mining height and the pillar safety factor $(\mathrm{SF})$. The Strength of the pillar is estimated using Bieniawski formula. The size of the pillar can be obtained by solving the non-linear equation 1 .

$$
1.1 \cdot h \cdot \frac{\left(W+W_{R}\right)^{2}}{W^{2}}=S F \cdot \sigma_{i}\left[0.64+0.36 \frac{W}{H}\right]
$$

Where $\mathrm{W}$ is the side length, $\mathrm{ft}$

$\sigma_{\mathrm{i}}$ is the in-situ strength of the coal, psi

$\mathrm{h}$ is the overburden depth, $\mathrm{ft}$

$\mathrm{W}_{\mathrm{r}}$ is the room width, $\mathrm{ft}$

$\mathrm{H}$ is the mining height, $\mathrm{ft}$ 
After calculating the size of the pillar that is the side length of the pillar, the recovery ratio of extraction of coal can be estimated by substituting the value of size of the pillar in the equation 2 given below.

$$
\eta=1-\frac{W^{2}}{\left(W+W_{R}\right)^{2}}
$$

The design parameters used in the calculation of the pillar size and the recovery ratio are mentioned below.

Mining Height: $\mathrm{H}=3,4,5,6,7,8,10,12$ and $15 \mathrm{ft}$

Room width: $\quad \mathrm{W}_{\mathrm{r}}=20 \mathrm{ft}$

Overall safety factor: $\mathrm{SF}=1.2$

Coal in-situ strength: $\sigma_{\mathrm{i}}=900 \mathrm{psi}$

\subsection{Determination of Pillar size}

Using the two equations above, the pillar size and the recovery ratio for a range of overburden depth have been determined. The required sizes of the square pillar (W) for a desired mining height $(\mathrm{m})$ at varying depth $(\mathrm{h})$ are plotted in the figure by solving equation 1 . It is considered that the size (W) of the pillar should be at least 3 times to that of the mining height to avoid slim pillars that form the condition for cascading pillar failure (CPF). A Cascading Pillar 
Failure $(\mathrm{CPF})$ event is a rapid failure of pillars in a large area that could cause serious safety problem to a mining operation.

The pillar sizes are estimated by performing regression on each of the curves derived. After the analysis it is found that the power function will fit each of the curves the best. The power function obtained from the regression is shown in equation 3 . The coefficients $a$ and $b$ are derived from the regression for each of the selected mining heights and are represented in the table 3 . The higher $\mathrm{R}^{2}$ values show that the derived regression functions can accurately represent the data.

$$
W(h)=A \times h^{B} \text { and } W(h) \geq 3 \cdot m
$$

Table 3: Derived Coefficients A and B for the Power Function in Pillar Size Design with

\section{Safety factor of 1.2}

\begin{tabular}{|l|l|l|l|l|l|l|l|l|l|}
\hline & $\mathrm{m}^{\prime} 3^{\prime}$ & $\mathrm{m}^{\prime} 4^{\prime}$ & $\mathrm{m}^{\prime} 5^{\prime}$ & $\mathrm{m}^{\prime} 6^{\prime}$ & $\mathrm{m}=7^{\prime}$ & $\mathrm{m}=8^{\prime}$ & $\mathrm{m}=10^{\prime}$ & $\mathrm{m}=12^{\prime}$ & $\mathrm{m}=15^{\prime}$ \\
\hline $\mathrm{A}$ & 0.4775 & 0.4193 & 0.3694 & 0.3273 & 0.3033 & 0.2715 & 0.2223 & 0.1920 & 0.1648 \\
\hline $\mathrm{B}$ & 0.5994 & 0.6396 & 0.6750 & 0.7066 & 0.7302 & 0.7569 & 0.8039 & 0.8406 & 0.8826 \\
\hline $\mathrm{R}^{2}$ & 0.9976 & 0.9979 & 0.9981 & 0.9984 & 0.9984 & 0.9987 & 0.9991 & 0.9993 & 0.9995 \\
\hline
\end{tabular}




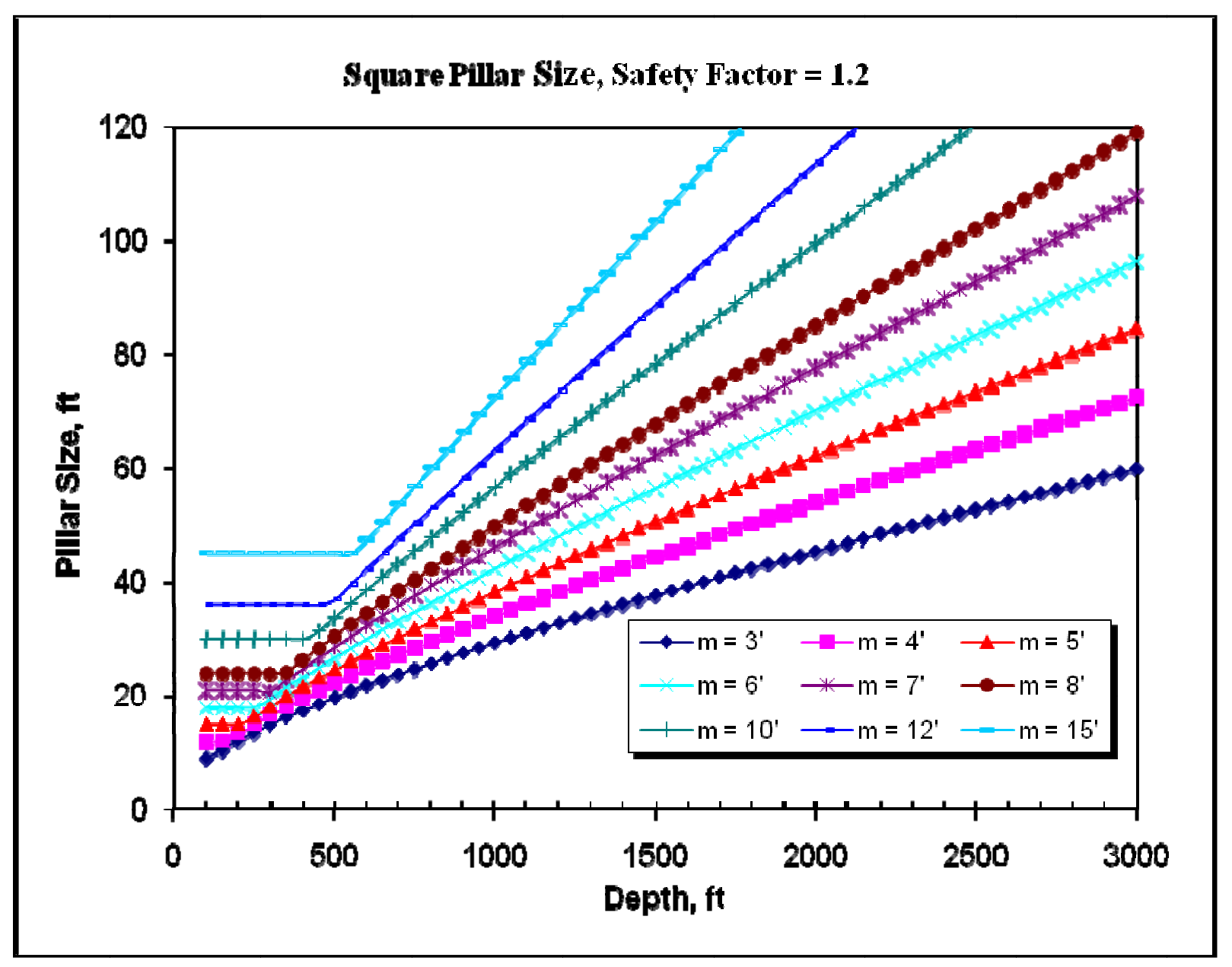

Figure 11: Sizes of the coal pillar at Different depths and Mining Heights

As the pillar sizes are estimated for different mining heights like 3, 4, 5, 6, 7, 8, 10, 12, 15 it is unnatural that the mining heights should be one of the above values. So in-order to make the calculation much easier, the relationship between the mining height $(\mathrm{m})$ and the coefficients $\mathrm{A}$ and $\mathrm{B}$ in the power function of equation 3 is studied. After the analysis it is found that the relationship between coefficient (A) and mining height $(\mathrm{m})$ can be represented by the following vapor pressure model. 


$$
A(m)=e^{(a+b / m+c \cdot \ln (m))}
$$

In the similar way the relationship between the coefficient $(\mathrm{B})$ and the mining height $(\mathrm{m})$ is represented by an exponential association function.

$$
B(m)=a \times\left(b-e^{-c \times m}\right)
$$

The coefficients for each of the two empirical functions are listed in Table 4.

\begin{tabular}{|c|c|c|c|c|c|c|c|c|}
\hline \multirow{7}{*}{ 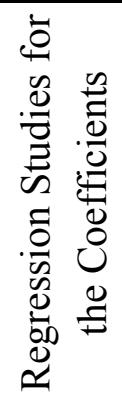 } & \multicolumn{4}{|c|}{ Coefficient a } & \multicolumn{4}{|c|}{ Coefficient $b$} \\
\hline & \multicolumn{4}{|c|}{ Vapor Pressure Model: } & \multicolumn{4}{|c|}{ Exponential Association: } \\
\hline & \multicolumn{4}{|c|}{$\mathrm{y}=\exp (\mathrm{a}+\mathrm{b} / \mathrm{x}+\mathrm{cln}(\mathrm{x}))$} & \multicolumn{4}{|c|}{$y=a(b-\exp (-c x))$} \\
\hline & \multicolumn{2}{|c|}{$a=$} & \multicolumn{2}{|c|}{0.94906} & \multicolumn{2}{|c|}{$a=$} & \multicolumn{2}{|c|}{0.54774} \\
\hline & \multicolumn{2}{|c|}{$b=$} & \multicolumn{2}{|c|}{-1.84890} & \multicolumn{2}{|c|}{$b=$} & \multicolumn{2}{|c|}{1.84267} \\
\hline & \multicolumn{2}{|c|}{$c=$} & \multicolumn{2}{|c|}{-0.97667} & \multicolumn{2}{|c|}{$c=$} & \multicolumn{2}{|c|}{0.09773} \\
\hline & \multicolumn{2}{|c|}{$R=$} & \multicolumn{2}{|c|}{0.99940} & \multicolumn{2}{|c|}{$R=$} & \multicolumn{2}{|c|}{0.99980} \\
\hline $\mathrm{m}$ & Original & Fit & Error & $\%$ Errol & Original & Fit & Error & $\%$ Errol \\
\hline 3 & 0.4775 & 0.4770 & 0.0005 & $0.10 \%$ & 0.5994 & 0.6008 & -0.0014 & $-0.23 \%$ \\
\hline 4 & 0.4193 & 0.4202 & -0.0009 & $-0.21 \%$ & 0.6396 & 0.6388 & 0.0008 & $0.13 \%$ \\
\hline 5 & 0.3694 & 0.3706 & -0.0012 & $-0.33 \%$ & 0.6750 & 0.6733 & 0.0017 & $0.25 \%$ \\
\hline 6 & 0.3273 & 0.3299 & -0.0026 & $-0.79 \%$ & 0.7066 & 0.7046 & 0.0020 & $0.29 \%$ \\
\hline 7 & 0.3033 & 0.2965 & 0.0068 & $2.23 \%$ & 0.7302 & 0.7329 & -0.0027 & $-0.38 \%$ \\
\hline 8 & 0.2715 & 0.2690 & 0.0025 & $0.91 \%$ & 0.7569 & 0.7587 & -0.0018 & $-0.23 \%$ \\
\hline 10 & 0.2223 & 0.2266 & -0.0043 & $-1.92 \%$ & 0.8039 & 0.8032 & 0.0007 & $0.09 \%$ \\
\hline 12 & 0.1920 & 0.1956 & -0.0036 & $-1.85 \%$ & 0.8406 & 0.8398 & 0.0008 & $0.10 \%$ \\
\hline 15 & 0.1648 & 0.1622 & 0.0026 & $1.59 \%$ & 0.8826 & 0.8828 & -0.0002 & $-0.03 \%$ \\
\hline
\end{tabular}

Table 4: Results of the regression studied for the coefficients $A$ and $B$ in the power function 
The relationship between the mining height $(\mathrm{m})$ and the coefficients A and B is plotted in the figure 7 and figure 8 .

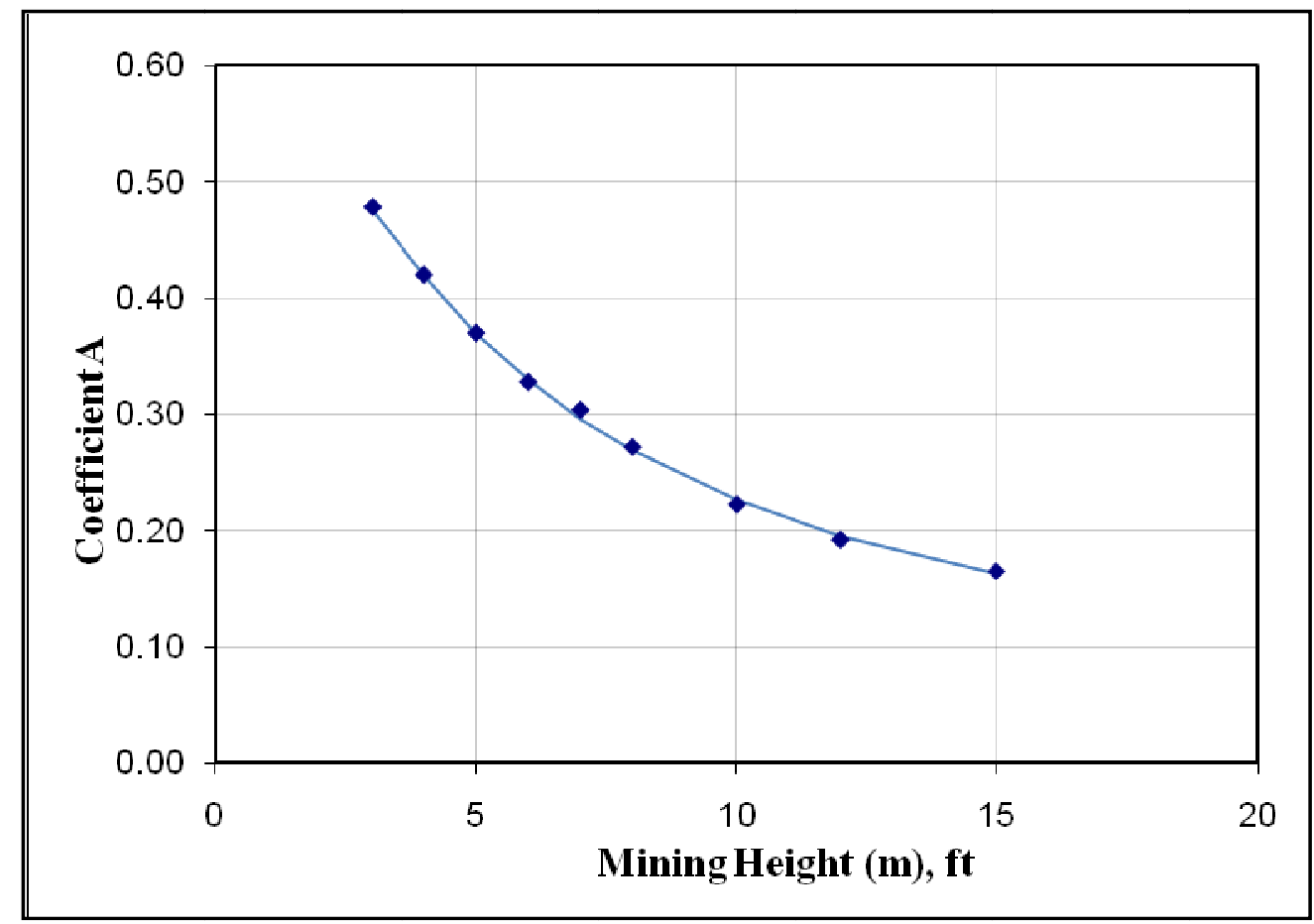

Figure 12: Relationship between Coefficient A and Mining Height (m) 


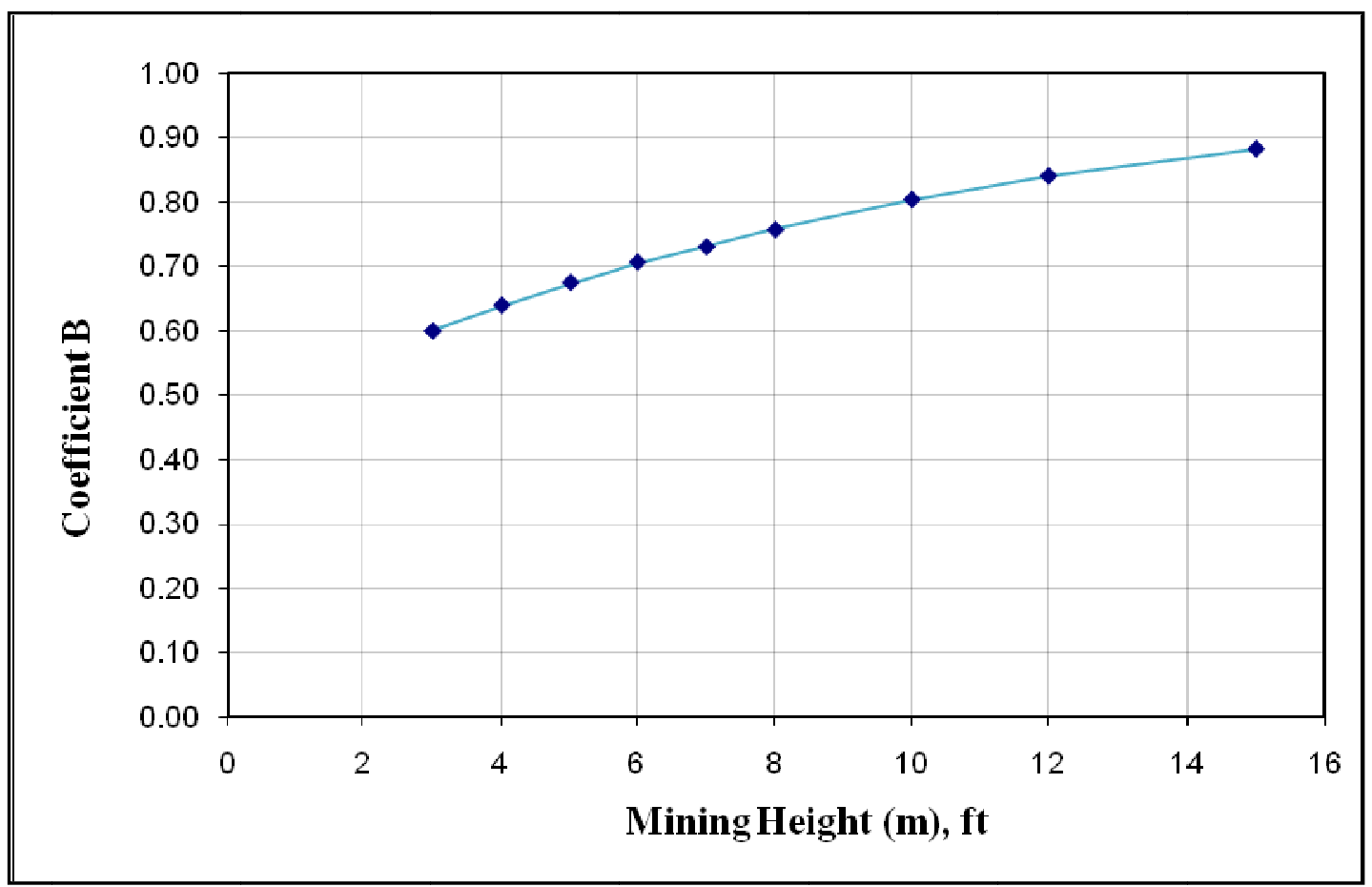

Figure 13: Relationship between Coefficient B and Mining Height (m)

\subsection{Determination of the Recovery Ratio:}

The recovery ratio of the pillar can be easily calculated once the size of the square pillar is determined. Using the equation 2 the recovery ratio for various mining heights and depths are calculated and plotted in the figure 9 . The recovery ratios greater than $75 \%$ are considered not to be practical. 


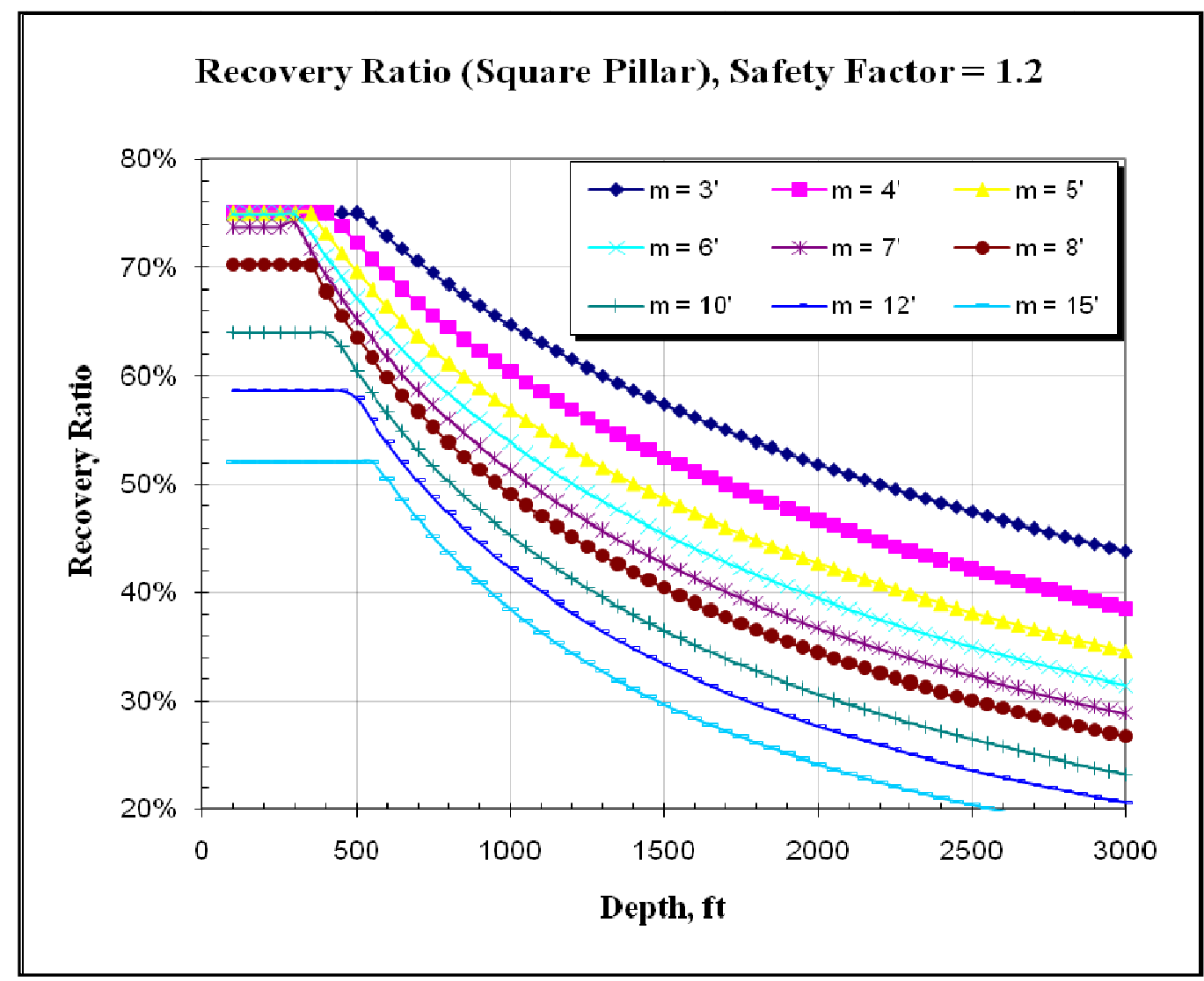

Figure 14: Recovery Ratios for Various Mining Height (m) and Depth (h)

\subsection{Example}

Determine the pillar size for a room and pillar coal mine that extracts a coal seam of $4.8 \mathrm{ft}$ thick at a depth of $800 \mathrm{ft}$.

At the mining height of $4.8 \mathrm{ft}$, the coefficients $\mathrm{A}$ and $\mathrm{B}$ for the power function (equation 3 ) are determined, using equations 4 and 5 , coefficient $A=0.7593$ and coefficient $B=0.6666$. By substituting these coefficients in equation 3, the size of the pillar at $800 \mathrm{ft}$ depth and a safety factor of 1.2 is $65.4 \mathrm{ft}$. The recovery ratio can be calculated by using equation 2 and is about 42 $\%$. 


\section{Mining Economics}

In an industrial system it is very important to assess the costs before developing it. Coal mining can be done only where the coal is technically feasible and economically profitable. So, it is important for us to assess the costs before extracting the ore. The most economic method of extraction mainly depends on the depth, thickness, geology of the coal seam and the environmental factors. Ventilation is often the second most essential auxiliary operations next to ground control in underground mining operations. In underground mines, good production and environment conditions can be satisfied by providing sufficient quantities of air to the work places. Under adverse conditions 10-20 tons of air has to be provided for each ton of coal produced. This involves a large cost, as there is huge energy consumption in order to the force the air to the mine openings. In order to decrease the ventilation cost suitable ventilation system must be designed which is functionally reliable and cost effective. As the coal mining will be conducted in deeper ground in the future, the ventilation cost will substantially increase.

The success of a mining company mainly depends on the cost of the product and the sales realization. This means that the costs for every mining operation have to be pre-calculated in order to have a good idea of the costs and prices. This is considered to be a very difficult task as it involves lot of variables which vary with different conditions. The wide variety use of equipment and variation in the working conditions makes very complex to get the results very accurately. Mining costs are mainly dependent on the nature of the deposit and the type of extraction. It is not like we use a lowest cost mining method to extract the ore but we should 
employ a method which result the lowest cost per unit of product when mining costs and treatment are considered together. Ventilation is the most useful and mostly used process underground because of the extent of its demand and it might get complicated and costly when the distance that air must travel from the surface to ventilation face is increased.

\subsection{Estimation of Ventilation Costs}

Mine ventilation cost is one of the major cost items in a coal mine operation. The methods in SME handbook for estimating the ventilation costs are used as the base methods for calculation. The base costs calculated from those methods are then adjusted by the coal seam (rank) and mine depth. The capital and operating costs for a ventilation system are entirely based on the horsepower requirement for the mine which in turn is dependent on the gas emission and fan head needed. (Hartman, H.L., 1992)

\subsection{Base method for Estimating Ventilation Requirement}

The ventilation requirement includes the quantity of the ventilation air (Q) and fan head (H). In SME handbook, these two values for coal mines are estimated using the following two equations based on daily production:

$$
\begin{aligned}
& Q=500 \times T^{0.8} \quad \text { cfm } \\
& H=2.4 \times T^{0.1} \text { inc es of water }
\end{aligned}
$$

Where $\mathrm{T}$ is daily production in Short Tons 
The installed fan horsepower (HP) is then estimated as

$$
H P=\frac{Q \times H}{3800} \quad h p
$$

\subsection{Ventilation Capital Cost}

In general, the most reliable method to estimate the capital cost for an installed ventilation system is the total installed horsepower (HP) of all ventilation fans in the system. For underground coal mines, the capital $\operatorname{cost}\left(\mathrm{C}_{\mathrm{c}}\right)$ is estimated by the following equation:

$$
C_{c}=7500 \times H P^{0.6}
$$

\subsection{Ventilation Operating Cost}

The ventilation operating costs is mainly the electricity cost. Since the ventilation system will operate year around, the annual operation cost for a mine ventilation system will be:

$$
C_{o}=0.75 \times H P \times 24 \times 365 \times c
$$

Where, $\mathrm{c}$ is the electricity cost per kilowatt-hour.

Based on this method the capital and the annual operating costs for a coal mine ventilation system are calculated for normal range of underground coal mine production and plotted in figure 15. 


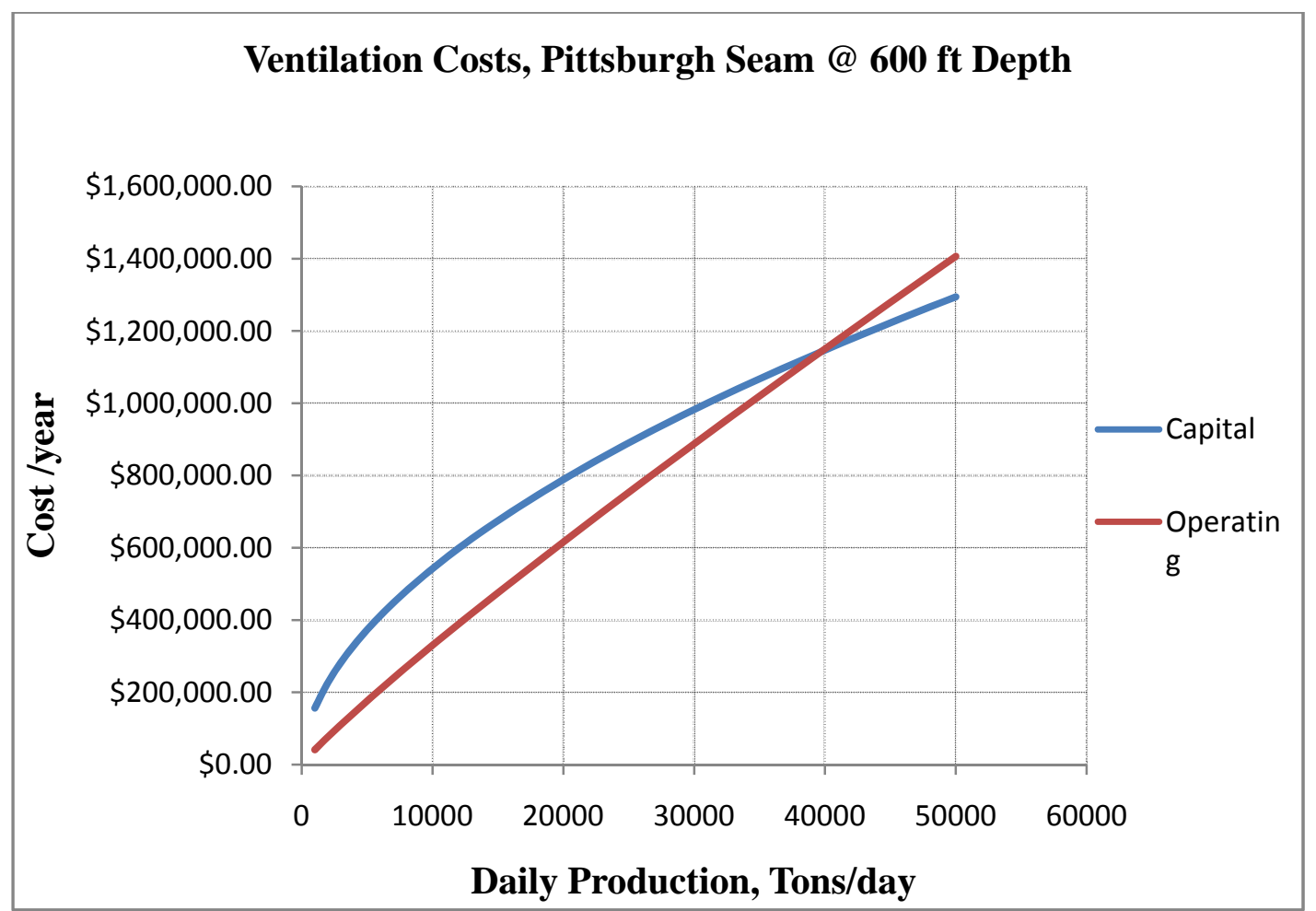

Figure 15: Base Capital and Annual Operating Costs of a Mine Ventilation System

\subsection{Adjustments to the Ventilation Requirement}

Underground coal mines are operated in different coal seams and at different depths. These differences make the gas content in a ton of the mined coal vary considerable. The required ventilation air quantity is to dilute the emitted gas to the underground to safe levels. It is assumed in this study that the gas emission is proportional to the gas content. It has been demonstrated by studies that the gas content in coal is function of the coal rank and mining depth (related to the reservoir pressure). Therefore, the required ventilation air quantity (Q) depends on the coal rank and mining depth. 


\subsection{Gas Content}

The gas content in a coal seam is the volume of methane in a ton of coal at standard condition (sea level and $70 \mathrm{~F}$. Unit: standard cubic $\mathrm{ft} / \mathrm{ton}$ of coal). The gas content of a coal seams increases mainly with depth and rank of the coal. The variation of the gas content in different coal seams in United States is shown below. There are different methods to estimate the gas content in a coal seam.

1. Direct method of estimation

2. NIOSH modified direct method and

3. Indirect method

\subsection{Indirect method to Estimate Gas Content}

The indirect method of estimating the gas contents in a coal is selected in this criterion. Most of the gases in coal are in absorbed state and the volume of the adsorbed gases mainly depends on the gas pressure in the buried condition. The figure 16 shows the graph showing gas contents of major US coal seams as the symbols. An indirect method to estimate gas content (Y) in coal seam at a particular depth (h) is shown in equation 6

$$
Y=\frac{Y_{c} B p}{1+B p}
$$


- Volume to cover and saturate the surface completely, $\mathrm{ft}^{3}$

B - Characteristic constant of the coal seam, atm ${ }^{-1}$

$\mathrm{p}$ - Reservoir pressure, atm, $\mathrm{p}=\mathrm{d} / 3 \mathrm{psi}=0.022682 \mathrm{~d}$ atm $(1 \mathrm{psi}=0.068046 \mathrm{~atm})$

b- Modified seam characteristic

h- Depth of seam, $\mathrm{ft}$

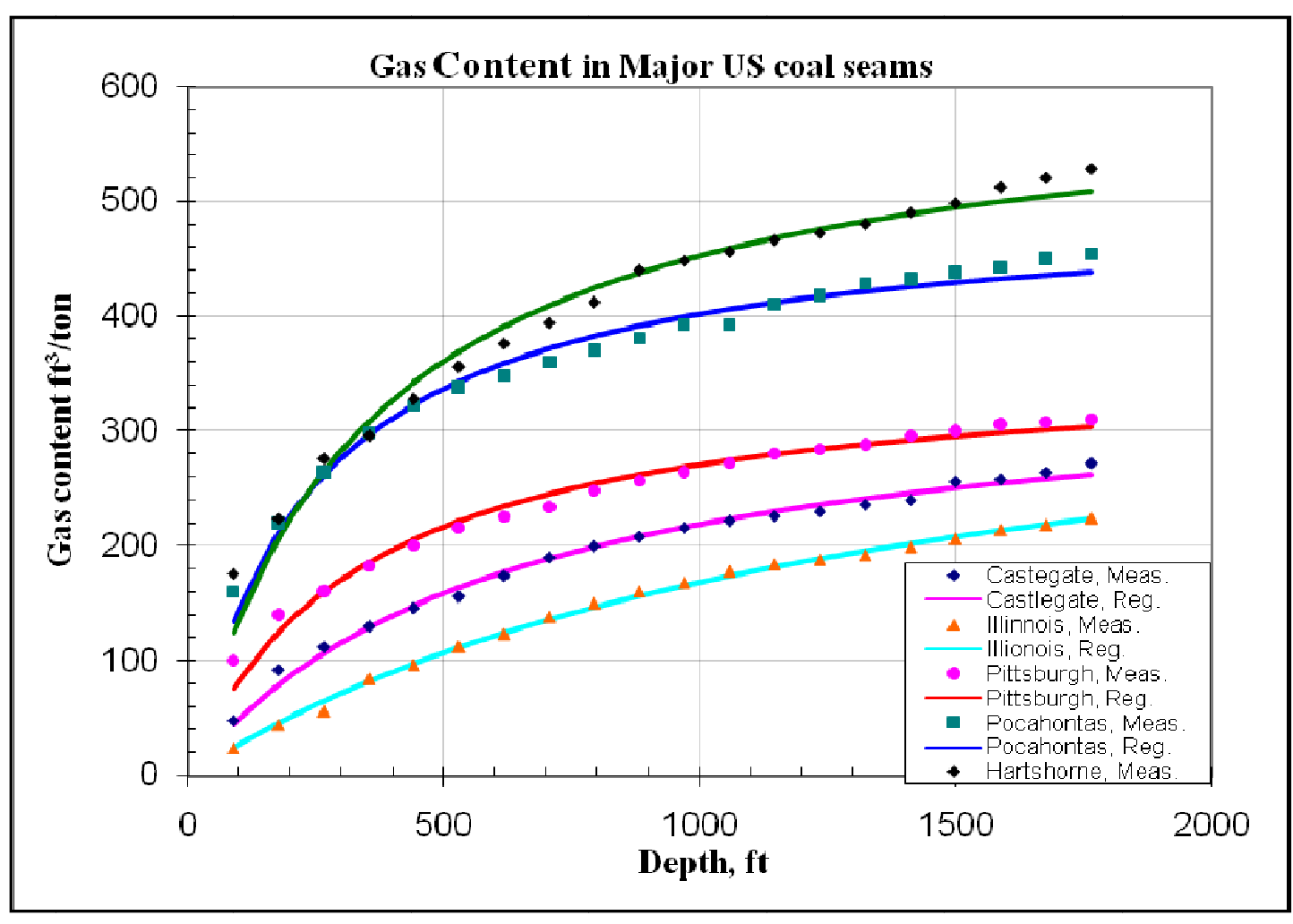

Figure 16: Gas Content in Major US Coal Seams 
Non linear regressions have been performed on the measured data and the coefficients of the coal seams are listed in table and the regression curves are plotted back into figure 16 . The high $\mathrm{r}$ values indicate good fitting to the data.

Table 5: Determined Regression Coefficients for the Selected Coal Seams

\begin{tabular}{|l|l|l|l|l|l|}
\hline Seam & Castlegate Seam & Illinois No.6 & Pittsburgh Seam & Pocahontas No.3 & Hartshorne Seam \\
\hline $\mathrm{Y}_{\mathrm{c}}=$ & 352.77 & 392.44 & 360.58 & 498.29 & 607.76 \\
\hline $\mathrm{b}=$ & 0.00164 & 0.00075 & 0.00301 & 0.00419 & 0.00293 \\
\hline $\mathrm{r}=$ & 0.9961 & 0.9990 & 0.9990 & 0.9907 & 0.9873 \\
\hline
\end{tabular}

\subsection{Correction Factor to Ventilation Air Quantity:}

It is assumed that the empirical equation for estimating the air quantity in the SME handbook is of the Pittsburgh coal seam at a depth of $600 \mathrm{ft}$. A correction factor should be applied for mining conducted in the other coal seams and at different depth. Based on this assumption, the empirical equation for the correction factors is shown in equation 7 and the coefficients in the empirical equation are listed in Table 2. The correction factors for different coal seams (S) and depth (h) are plotted in the figure. And the adjusted air quantity is estimated by using the equation 8 .

$$
\begin{aligned}
& C(S, h)=\frac{a b h}{1+b h} \\
& Q^{\prime}=Q \times C(S, h)
\end{aligned}
$$


Table 6: Coefficients for Correction Factor for the Selected Coal Seams

\begin{tabular}{|l|l|l|l|l|l|}
\hline Seam & Castlegate Seam & Illinois No.6 & Pittsburgh Seam & Pocahontas No.3 & Hartshorne Seam \\
\hline $\mathrm{a}=$ & 1.58 & 1.76 & 1.62 & 2.23 & 2.73 \\
\hline $\mathrm{b}=$ & 0.00164 & 0.00075 & 0.00301 & 0.00419 & 0.00293 \\
\hline $\mathrm{r}$ & 0.9961 & 0.9990 & 0.9990 & 0.9907 & 0.9873 \\
\hline
\end{tabular}

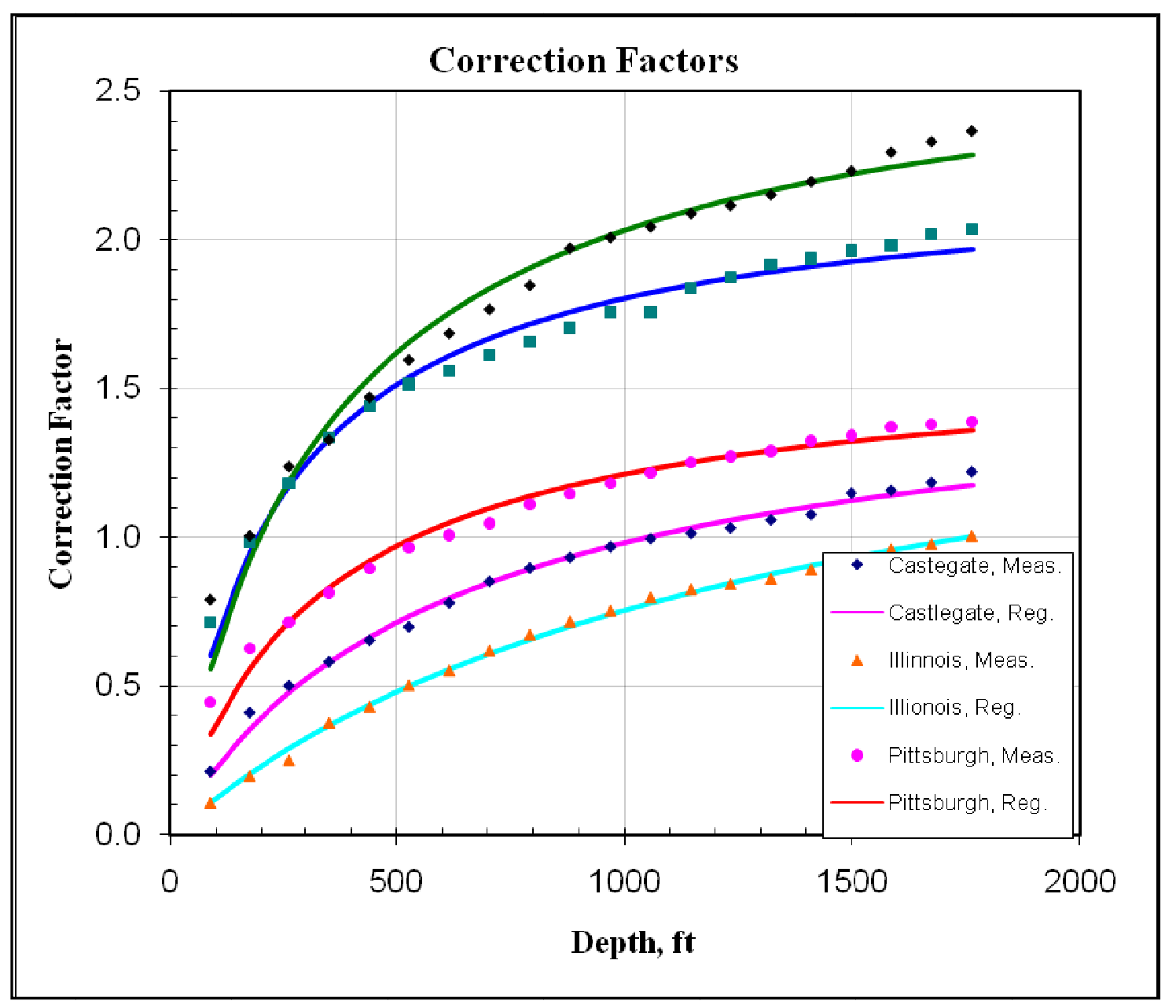

Figure 17: Correction Factors for Required Ventilation Air Quantity 
The percentage of ventilation costs to total costs of producing each ton of coal is calculated after adjusting the quantity requirement. This is calculated for different coal seams occurring at different depths and plotted in the graph below.

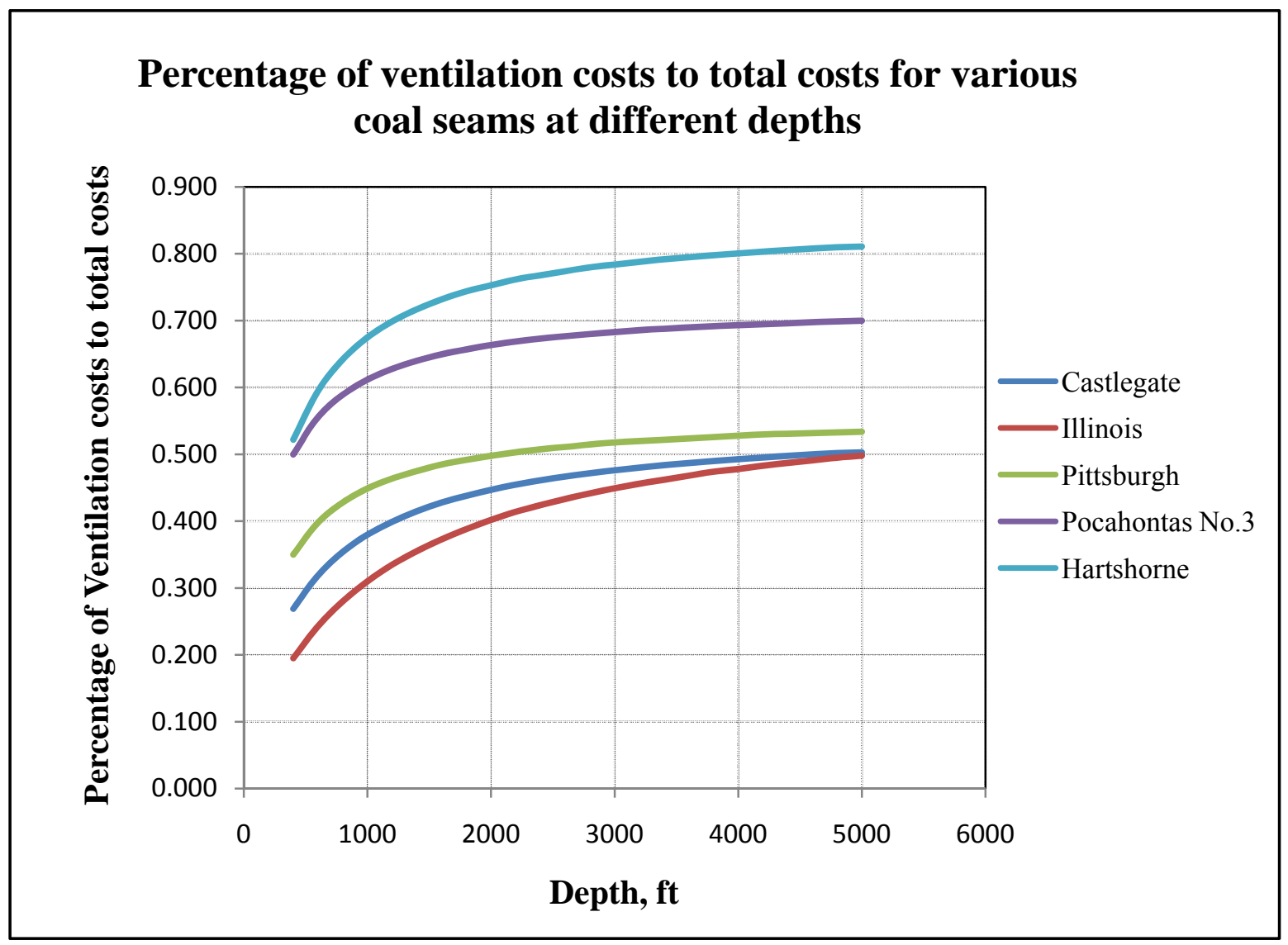

Figure 18: Graph showing the percentage of ventilation costs to total costs for different coal seams at varying depths. 


\subsection{Example:}

Determine the ventilation requirement and ventilation costs for a coal mine extracting in the Hartshorne seam at a depth of $1800 \mathrm{ft}$. the daily production is 20,000 tons and electricity cost is \$0.04/Kilo watt-hour.

Based on SME handbook method and the above adjustments, the ventilation requirement is determined. The air quantity required is first estimated by using the base methods of SME and then later a correction factor for the given seam is applied and the adjusted air quantity is calculated. The capital and operating costs are further calculated by using the adjusted air quantity.

Quantity $=1,379,730$ cubic feet per min

$\mathrm{H}=6.46$ inches of water

Correction factor, $\mathrm{C}(\mathrm{S}, \mathrm{h})=2.29$

Adjusted Air Quantity, $Q^{\prime}=3,166,200$ cubic feet per min

Horse Power $=5,383 \mathrm{hp}$

Capital cost $C_{c}=\$ 1,299,200$

Annual operating cost $\mathrm{C}_{\mathrm{o}}=\$ 1,414,650$ 


\section{Conclusion}

This thesis discusses the coal resource assessment and the use of ARC GIS software to project the information regarding different characteristics of coal, production scenarios, reserve availability, on a map. This makes the users much more convenient than to go through the tables and analyze the data for reference. The query builder in this software is mainly used to acquire the desired results. Analysis of these coal resources has implied the demand of coal in the present era and that forced us to extract coal under more challenging conditions than those exist today. With the increase in depth the implementation of more advanced technologies with various techniques to improve the recoverability of coal has been made. The recoverability of extraction is estimated for room and pillar mining in this study for various geological conditions. This is considered to be a good approximation as the size of the pillar and the recovery ratio of extraction can be readily determined for a given mining height and depth. The analysis of the costs especially the ventilation costs involved in the extraction of deep coal deposits is done in this study. The advantage of this analysis is that the user can obtain the percentage of the ventilation costs in the total production costs readily in a given geological conditions. As the study is mainly done on the major coal seams, the estimations are also limited to the same. 


\section{References}

1. World Coal Institute, http://www.worldcoal.org/coal/uses-of-coal/, 12/02/2009.

2. Coal Basics, Energy Information

Administration, http://tonto.eia.doe.gov/kids/energy.cfm?page=coal_home-basics, $11 / 20 / 2009$

3. Coal Types, Appalachian Blacksmiths

Association, http://www.appaltree.net/aba/coaltypes.htm, 11/24/2009

4. All About Coal, American Coal

Foundation http://www.teachcoal.org/aboutcoal/articles/coalppf.html, 10/25/2009.

5. Coal Reserves Data, Energy Information

Administration, http://www.eia.doe.gov/cneaf/coal/reserves/chapter1.html, 10/24/2009

6. US Coal Resource Database, National Coal Resources Data

System, http://energy.er.usgs.gov/coalres.htm, United States Geological Survey (USGS)

7. Luppens, J.A., Rohrbacher, T.J., Osmonson, L.M., and Carter, M.D., 2009, Coal resource availability, recoverability, and economic evaluations in the United States-A Summary, pp.1,3.

8. EIA., 2006, Coal Production in United States, pp.1,2.

9. Energy Watch Group., 2007, Coal: Resources and Future Production, Final-Version 28032007, EWG-Series No 1/2007, pp.31.

10. United States Coal Regions, Coal, Wikipedia, http://en.wikipedia.org/wiki/File:Us_coal_regions_1996.png 11/15/2009

11. Hartman, H.L., Mutmansky, J.M., and Wang, Y.J., 1982, Mine Ventilation and Air Conditioning, $2^{\text {nd }}$ ed, New York: Wiley, pp. 421,449 \& 561.

12. Shurick, A. T., 1922, Coal Mining Costs, $1^{\text {st }}$ ed, INC New York [etc.] McGraw-Hill Book Company, Inc., pp. 10-30 \& 443. 
13. Hartman, H.L., and Mutmansky, J.M., 2002, Introductory Mining Engineering, $2^{\text {nd }}$ ed, Hoboken, N.J.: J. Wiley, pp. 323 \& 405.

14. Mine Cost Models, U.S Bureau of Mines, http://www.minecost.com/models.htm, Aug 2009.

15. Hartman, H.L., 1992, SME Mining Engineering Handbook, Volume 1, Littleton, Co:

SME, pp.2049.

16. Energy Information Administration, Annual Coal Report 2008, Report No.: DOE/EIA 0584 (2008) Report Released: September 18, 2009, (http://www.eia.doe.gov/cneaf/coal/page/acr/acr_sum.html)

17. Mark, C., 2006, The Evolution of Intelligent Coal Pillar Design: 1981-2006, Proceedings of 25th International Conference on Ground Control in Mining, pp.325-334.

18. Mark, C., Chase, F., and Pappas, D., 2003, Reducing the Risk of Ground Falls during Pillar Recovery, SME preprint 03-137. Littleton, CO: SME, pp.1-7.

19. Support, Environmental Systems Research Institute, http://support.esri.com/. 


\section{Appendix 1: DATABASES USED IN THE SOFTWARE}

Conventions used:

MST: Million Short Tons

TST: Thousand Short Tons

BIT: Bituminous

SUBBIT: Sub-bituminous

Table 7: Average sale price of coal by state and coal rank, 2008

(Source: Annual Coal Report 2008, EIA)

\begin{tabular}{|c|c|c|c|c|c|c|}
\hline State & FIPS & Bituminous $(\$)$ & $\begin{array}{l}\text { Sub- } \\
\text { Bituminous }(\$)\end{array}$ & Lignite(\$) & Anthracite(\$) & Total $(\$)$ \\
\hline Alabama & 01 & 71.31 & - & - & - & 71.31 \\
\hline Alaska & 02 & - & $\mathrm{W}$ & - & - & $\mathrm{W}$ \\
\hline Arizona & 04 & $\mathrm{~W}$ & - & - & - & W \\
\hline Arkansas & 05 & $\mathrm{~W}$ & - & - & - & $\mathrm{W}$ \\
\hline Colorado & 08 & $\mathrm{~W}$ & $\mathrm{~W}$ & - & - & 32.67 \\
\hline Illinois & 17 & 40.3 & - & - & - & 40.3 \\
\hline Indiana & 18 & 34.95 & - & - & - & 34.95 \\
\hline Kansas & 20 & $\mathrm{~W}$ & - & - & - & $\mathrm{W}$ \\
\hline Kentucky & 21 & 51.32 & - & - & - & 51.32 \\
\hline Louisiana & 22 & - & - & $\mathrm{W}$ & - & $\mathrm{W}$ \\
\hline Maryland & 24 & 42.19 & - & - & - & 42.19 \\
\hline Mississippi & 28 & - & - & W & - & $\mathrm{W}$ \\
\hline Missouri & 29 & $\mathrm{~W}$ & - & - & - & $\mathrm{W}$ \\
\hline Montana & 30 & - & $\mathrm{W}$ & $\mathrm{W}$ & - & 12.31 \\
\hline New Mexico & 35 & $\mathrm{~W}$ & W & - & - & 33.16 \\
\hline North Dakota & 38 & - & - & 12.92 & - & 12.92 \\
\hline
\end{tabular}




\begin{tabular}{|c|c|c|c|c|c|c|}
\hline Ohio & 39 & 41.4 & - & - & - & 41.4 \\
\hline Oklahoma & 40 & 47.72 & - & - & - & 47.72 \\
\hline Pennsylvania & 42 & 50.52 & - & - & 60.76 & 50.77 \\
\hline Tennessee & 47 & 48.94 & - & - & - & 48.94 \\
\hline Texas & 48 & - & - & 18.16 & - & 18.16 \\
\hline Utah & 49 & 26.39 & - & - & - & 26.39 \\
\hline Virginia & 51 & 84.57 & - & - & - & 84.57 \\
\hline $\begin{array}{l}\text { West } \\
\text { Virginia }\end{array}$ & 54 & 60.21 & - & - & - & 60.21 \\
\hline Wyoming & 56 & $\mathrm{~W}$ & $\mathrm{~W}$ & - & - & 11.39 \\
\hline United & & 51.4 & 12.31 & 16.5 & 60.76 & 31.26 \\
\hline
\end{tabular}


Table 8: Coal Production and Number of Mines by State, County and Mine Type

(Source: Annual Coal Report 2008, EIA)

\begin{tabular}{|c|c|c|c|c|c|c|c|}
\hline State & County & $\begin{array}{l}\text { Number } \\
\text { of Mines } \\
\text { U/G }\end{array}$ & $\begin{array}{c}\text { Production U/G } \\
\text { (in MST) }\end{array}$ & $\begin{array}{l}\text { Number of } \\
\text { Mines Surface }\end{array}$ & $\begin{array}{l}\text { Production } \\
\text { surface } \\
\text { (in MST) }\end{array}$ & $\begin{array}{l}\text { Total } \\
\text { Number of } \\
\text { Mines }\end{array}$ & $\begin{array}{l}\text { Total } \\
\text { Production } \\
\text { (in MST) }\end{array}$ \\
\hline $\mathrm{AL}$ & Bibb & - & - & 1 & 105 & 1 & 105 \\
\hline $\mathrm{AL}$ & Cullman & - & - & 2 & 154 & 2 & 154 \\
\hline $\mathrm{AL}$ & Fayette & 1 & 2,923 & - & - & 1 & 2,923 \\
\hline $\mathrm{AL}$ & Franklin & - & - & 2 & 297 & 2 & 297 \\
\hline $\mathrm{AL}$ & Jackson & - & - & 4 & 331 & 4 & 331 \\
\hline $\mathrm{AL}$ & Jefferson & 2 & 3,091 & 8 & 1,311 & 10 & 4,402 \\
\hline $\mathrm{AL}$ & Marion & - & - & 1 & 50 & 1 & 50 \\
\hline $\mathrm{AL}$ & Shelby & 2 & 87 & 4 & 452 & 6 & 539 \\
\hline $\mathrm{AL}$ & Tuscaloosa & 2 & 6,039 & 7 & 1,826 & 9 & 7,865 \\
\hline $\mathrm{AL}$ & Walker & 1 & 141 & 19 & 3,190 & 20 & 3,331 \\
\hline \multirow[t]{3}{*}{$\mathrm{AL}$} & Winston & - & - & 3 & 616 & 3 & 616 \\
\hline & Yukon- & & & & & & \\
\hline & Koyukuk & & & & & & \\
\hline $\mathrm{AK}$ & Division & - & - & 1 & 1,477 & 1 & 1,477 \\
\hline
\end{tabular}




$\begin{array}{llllllll}\text { AZ } & \text { Navajo } & - & - & 1 & 8,025 & 1 & 8,025 \\ \text { AR } & \text { Sebastian } & 1 & 67 & 1 & 2 & 2 & 69 \\ \text { CO } & \text { Adams } & - & - & 1 & 21 & 1 & 21 \\ \text { CO } & \text { Delta } & 1 & 2,862 & - & - & 1 & 2,862 \\ \text { CO } & \text { Garfield } & 1 & 283 & - & - & 1 & 283 \\ \text { CO } & \text { Gunnison } & 2 & 10,761 & - & - & 2 & 10,761 \\ \text { CO } & \text { La Plata } & 2 & 392 & - & - & 2 & 392 \\ \text { CO } & \text { Moffat } & - & - & 2 & 7,235 & 2 & 7,235 \\ \text { CO } & \text { Montrose } & - & - & 1 & 403 & 1 & 403 \\ \text { CO } & \text { Rio Blanco } & 1 & 2,067 & - & - & 1 & 2,067 \\ \text { CO } & \text { Routt } & 1 & 8,004 & - & - & 1 & 8,004 \\ \text { IL } & \text { Gallatin } & - & - & 2 & 2,322 & 2 & 2,322 \\ \text { IL } & \text { Jackson } & 1 & 196 & 2 & 1,387 & 3 & 1,582 \\ \text { IL } & \text { Macoupin } & 1 & 1,408 & - & - & 1 & 1,408 \\ \text { IL } & \text { Perry } & 1 & 1,112 & 3 & 1,118 & 4 & 2,230 \\ \text { IL } & \text { Randolph } & 1 & 3,198 & - & - & 1 & 3,198 \\ \text { IL } & \text { Saline } & 3 & 9,594 & - & - & 3 & 9,594 \\ \text { IL } & \text { Sangamon } & 1 & 2,261 & - & - & 1 & 2,261 \\ \text { IL } & \text { Vermilion } & 1 & 1,130 & - & - & 1 & 1,130 \\ \text { IL } & \text { Wabash } & - & - & 1 & 1,037 & 1 & 1,037\end{array}$




\begin{tabular}{|c|c|c|c|c|c|c|c|}
\hline IL & White & 1 & 2,653 & - & - & 1 & 2,653 \\
\hline IL & Williamson & 1 & 5,504 & - & - & 1 & 5,504 \\
\hline $\mathrm{IN}$ & Daviess & - & - & 3 & 3,566 & 3 & 3,566 \\
\hline $\mathrm{IN}$ & Dubois & - & - & 1 & 846 & 1 & 846 \\
\hline IN & Gibson & 2 & 5,340 & 4 & 9,398 & 6 & 14,738 \\
\hline IN & Knox & 2 & 2,548 & 4 & 3,190 & 6 & 5,738 \\
\hline IN & Pike & 1 & 2,365 & 6 & 1,894 & 7 & 4,259 \\
\hline IN & Sullivan & 1 & 1,970 & 1 & 107 & 2 & 2,077 \\
\hline IN & Vigo & - & - & 2 & 3,805 & 2 & 3,805 \\
\hline IN & Warrick & - & - & 3 & 865 & 3 & 865 \\
\hline KS & Bourbon & - & - & 1 & 181 & 1 & 181 \\
\hline KS & Linn & - & - & 1 & 48 & 1 & 48 \\
\hline KY & Bell & 5 & 957 & 19 & 2,403 & 24 & 3,360 \\
\hline KY & Breathitt & 2 & 1,052 & 6 & 969 & 8 & 2,021 \\
\hline KY & Christian & - & - & 1 & 4 & 1 & 4 \\
\hline KY & Clay & 1 & 4 & 7 & 242 & 8 & 246 \\
\hline KY & Daviess & - & - & 1 & 342 & 1 & 342 \\
\hline KY & Elliott & - & - & 1 & 38 & 1 & 38 \\
\hline KY & Floyd & 26 & 2,058 & 16 & 3,818 & 42 & 5,876 \\
\hline KY & Harlan & 34 & 7,793 & 25 & 3,128 & 59 & 10,920 \\
\hline
\end{tabular}




$\begin{array}{llllllll}\text { KY } & \text { Henderson } & 1 & 1,462 & 2 & 1,358 & 3 & 2,820 \\ \text { KY } & \text { Hopkins } & 4 & 14,175 & 1 & 80 & 5 & 14,255 \\ \text { KY } & \text { Jackson } & - & - & 2 & 45 & 2 & 45 \\ \text { KY } & \text { Johnson } & 2 & 281 & 8 & 748 & 10 & 1,028 \\ \text { KY } & \text { Knott } & 26 & 4,938 & 14 & 2,598 & 40 & 7,536 \\ \text { KY } & \text { Knox } & 3 & 80 & 6 & 363 & 9 & 443 \\ \text { KY } & \text { Laurel } & - & - & 4 & 35 & 4 & 35 \\ \text { KY } & \text { Lawrence } & - & - & 10 & 622 & 10 & 622 \\ \text { KY } & \text { Leslie } & 7 & 2,215 & 9 & 2,405 & 16 & 4,620 \\ \text { KY } & \text { Letcher } & 24 & 4,645 & 15 & 886 & 39 & 5,531 \\ \text { KY } & \text { Magoffin } & 1 & 16 & 12 & 3,412 & 13 & 3,427 \\ \text { KY } & \text { Martin } & 8 & 3,480 & 7 & 2,212 & 15 & 5,693 \\ \text { KY } & \text { Morgan } & - & - & 2 & 205 & 2 & 205 \\ \text { KY } & \text { Muhlenberg } & 1 & 2,235 & 6 & 2,142 & 7 & 4,377 \\ \text { KY } & \text { Ohio } & 1 & 584 & 1 & 807 & 2 & 1,391 \\ \text { KY } & \text { Owsley } & - & - & 3 & 57 & 3 & 57 \\ \text { KY } & \text { Perry } & 8 & 4,132 & 32 & 13,040 & 40 & 17,172 \\ \text { KY } & \text { Pike } & 56 & 12,355 & 41 & 8,659 & 97 & 21,014 \\ \text { KY } & \text { Union } & 2 & 4,884 & - & - & 2 & 4,884 \\ \text { KY } & \text { Webster } & 2 & 1,990 & - & - & 2 & 1,990\end{array}$




$\begin{array}{llllllll}\text { KY } & \text { Whitley } & 2 & 137 & 2 & 234 & 4 & 371 \\ \text { LA } & \text { De Soto } & - & - & 1 & 3,285 & 1 & 3,285 \\ \text { LA } & \text { Red River } & - & - & 1 & 559 & 1 & 559 \\ \text { MD } & \text { Allegany } & 1 & 431 & 13 & 1,490 & 14 & 1,920 \\ \text { MD } & \text { Garrett } & 1 & 322 & 6 & 617 & 7 & 940 \\ \text { MS } & \text { Choctaw } & - & - & 1 & 2,842 & 1 & 2,842 \\ \text { MO } & \text { Bates } & - & - & 2 & 247 & 2 & 247 \\ \text { MT } & \text { Big Horn } & - & - & 3 & 31,210 & 3 & 31,210 \\ \text { MT } & \text { Musselshell } & 1 & 168 & - & - & 1 & 168 \\ \text { MT } & \text { Richland } & - & - & 1 & 355 & 1 & 355 \\ \text { MT } & \text { Rosebud } & - & - & 1 & 13,053 & 1 & 13,053 \\ \text { NM } & \text { McKinley } & - & - & 3 & 9,693 & 3 & 9,693 \\ \text { NM } & \text { San Juan } & 1 & 7,046 & 1 & 8,906 & 2 & 15,952 \\ \text { ND } & \text { McLean } & - & - & 1 & 7,533 & 1 & 7,533 \\ \text { ND } & \text { Mercer } & - & - & 2 & 17,589 & 2 & 17,589 \\ \text { ND } & \text { Oliver } & - & - & 1 & 4,505 & 1 & 4,505 \\ \text { OH } & \text { Belmont } & 1 & 5,798 & 5 & 1,076 & 6 & 6,873 \\ \text { OH } & \text { Carroll } & 1 & 110 & 2 & 39 & 3 & 149 \\ \text { OH } & \text { Columbiana } & - & - & 4 & 351 & 4 & 351 \\ \text { OH } & \text { Coshocton } & - & - & 249 & 2 & 249\end{array}$




\begin{tabular}{|c|c|c|c|c|c|c|c|}
\hline $\mathrm{OH}$ & Harrison & 1 & 1,536 & 7 & 1,726 & 8 & 3,262 \\
\hline $\mathrm{OH}$ & Jackson & - & - & 1 & 374 & 1 & 374 \\
\hline $\mathrm{OH}$ & Jefferson & 4 & 923 & 2 & 1,512 & 6 & 2,435 \\
\hline $\mathrm{OH}$ & Lawrence & - & - & 1 & 3 & 1 & 3 \\
\hline $\mathrm{OH}$ & Mahoning & - & - & 2 & 8 & 2 & 8 \\
\hline $\mathrm{OH}$ & Monroe & 1 & 6,844 & - & - & 1 & 6,844 \\
\hline $\mathrm{OH}$ & Muskingum & - & - & 1 & 165 & 1 & 165 \\
\hline $\mathrm{OH}$ & Noble & - & - & 2 & 791 & 2 & 791 \\
\hline $\mathrm{OH}$ & Perry & 2 & 1,418 & 2 & 648 & 4 & 2,066 \\
\hline $\mathrm{OH}$ & Stark & - & - & 2 & 368 & 2 & 368 \\
\hline $\mathrm{OH}$ & Tuscarawas & 1 & 425 & 3 & 1,211 & 4 & 1,636 \\
\hline $\mathrm{OH}$ & Vinton & - & - & 1 & 677 & 1 & 677 \\
\hline $\mathrm{OK}$ & Craig & - & - & 1 & 261 & 1 & 261 \\
\hline $\mathrm{OK}$ & Haskell & - & - & 1 & 169 & 1 & 169 \\
\hline $\mathrm{OK}$ & Le Flore & 1 & 441 & 2 & 423 & 3 & 864 \\
\hline $\mathrm{OK}$ & Okmulgee & - & - & 1 & 1 & 1 & 1 \\
\hline $\mathrm{OK}$ & Rogers & - & - & 1 & 168 & 1 & 168 \\
\hline PA & Allegheny & - & - & 4 & 121 & 4 & 121 \\
\hline PA & Armstrong & 8 & 2,873 & 10 & 831 & 18 & 3,704 \\
\hline PA & Beaver & 1 & 380 & - & - & 1 & 380 \\
\hline
\end{tabular}




\begin{tabular}{|c|c|c|c|c|c|c|c|}
\hline PA & Bedford & - & - & 2 & 4 & 2 & 4 \\
\hline PA & Butler & - & - & 6 & 599 & 6 & 599 \\
\hline PA & Cambria & 2 & 872 & 9 & 408 & 11 & 1,281 \\
\hline PA & Cameron & - & - & 1 & 31 & 1 & 31 \\
\hline PA & Centre & - & - & 1 & 12 & 1 & 12 \\
\hline PA & Clarion & - & - & 5 & 448 & 5 & 448 \\
\hline PA & Clearfield & 2 & 1,341 & 46 & 2,914 & 48 & 4,255 \\
\hline PA & Columbia & - & - & 4 & 149 & 4 & 149 \\
\hline PA & Dauphin & 2 & 34 & - & - & 2 & 34 \\
\hline PA & Elk & 1 & 220 & 6 & 307 & 7 & 527 \\
\hline PA & Fayette & - & - & 12 & 489 & 12 & 489 \\
\hline PA & Greene & 7 & 41,388 & 1 & 5 & 8 & 41,393 \\
\hline PA & Huntingdon & - & - & 1 & 6 & 1 & 6 \\
\hline PA & Indiana & 8 & 2,165 & 18 & 537 & 26 & 2,702 \\
\hline PA & Jefferson & 1 & 157 & 11 & 452 & 12 & 609 \\
\hline PA & Lackawanna & - & - & 2 & 22 & 2 & 22 \\
\hline PA & Luzerne & - & - & 7 & 211 & 7 & 211 \\
\hline PA & Lycoming & - & - & 1 & 257 & 1 & 257 \\
\hline PA & Northumberland & 3 & 148 & 5 & 82 & 8 & 231 \\
\hline
\end{tabular}




\begin{tabular}{|c|c|c|c|c|c|c|c|}
\hline PA & Schuylkill & 8 & 59 & 35 & 995 & 43 & 1,054 \\
\hline PA & Somerset & 7 & 1,843 & 18 & 2,694 & 25 & 4,537 \\
\hline PA & Tioga & - & - & 1 & 2 & 1 & 2 \\
\hline PA & Venango & - & - & 1 & 13 & 1 & 13 \\
\hline PA & Washington & 1 & 1,838 & 3 & 471 & 4 & 2,309 \\
\hline PA & Westmoreland & - & - & 5 & 34 & 5 & 34 \\
\hline $\mathrm{TN}$ & Anderson & 1 & 37 & 2 & 148 & 3 & 185 \\
\hline $\mathrm{TN}$ & Campbell & 3 & 387 & 7 & 409 & 10 & 796 \\
\hline $\mathrm{TN}$ & Claiborne & 1 & 364 & 8 & 966 & 9 & 1,330 \\
\hline $\mathrm{TN}$ & Fentress & - & - & 1 & 22 & 1 & 22 \\
\hline $\mathrm{TX}$ & Atascosa & - & - & 1 & 3,079 & 1 & 3,079 \\
\hline $\mathrm{TX}$ & Freestone & - & - & 1 & 3,339 & 1 & 3,339 \\
\hline $\mathrm{TX}$ & Harrison & - & - & 1 & 4,055 & 1 & 4,055 \\
\hline $\mathrm{TX}$ & Hopkins & - & - & 1 & 1,943 & 1 & 1,943 \\
\hline $\mathrm{TX}$ & Lee & - & - & 1 & 3,754 & 1 & 3,754 \\
\hline $\mathrm{TX}$ & Leon & - & - & 1 & 6,454 & 1 & 6,454 \\
\hline TX & Panola & - & - & 2 & 6,886 & 2 & 6,886 \\
\hline $\mathrm{TX}$ & Robertson & - & - & 1 & 2,122 & 1 & 2,122 \\
\hline TX & Rusk & - & - & 1 & 4,655 & 1 & 4,655 \\
\hline TX & Titus & - & - & 1 & 2,730 & 1 & 2,730 \\
\hline
\end{tabular}




$\begin{array}{llllllll}\text { UT } & \text { Carbon } & 5 & 11,545 & - & - & 5 & 11,545 \\ \text { UT } & \text { Emery } & 3 & 5,874 & - & - & 3 & 5,874 \\ \text { UT } & \text { Sevier } & 1 & 6,946 & - & - & 1 & 6,946 \\ \text { VA } & \text { Buchanan } & 23 & 5,596 & 18 & 2,843 & 41 & 8,439 \\ \text { VA } & \text { Dickenson } & 10 & 1,804 & 5 & 266 & 15 & 2,070 \\ \text { VA } & \text { Lee } & 1 & 326 & 3 & 830 & 4 & 1,156 \\ \text { VA } & \text { Russell } & 6 & 952 & 3 & 181 & 9 & 1,134 \\ \text { VA } & \text { Tazewell } & 4 & 650 & 1 & 95 & 5 & 745 \\ \text { VA } & \text { Wise } & 21 & 6,477 & 19 & 4,691 & 40 & 11,169 \\ \text { WV } & \text { Barbour } & 4 & 1,466 & 4 & 634 & 8 & 2,100 \\ \text { WV } & \text { Boone } & 27 & 12,660 & 14 & 17,918 & 41 & 30,578 \\ \text { WV } & \text { Brooke } & - & - & 2 & 524 & 2 & 524 \\ \text { WV } & \text { Clay } & 1 & 291 & 1 & 3,310 & 2 & 3,600 \\ \text { WV } & \text { Fayette } & 9 & 2,578 & 13 & 4,468 & 22 & 7,046 \\ \text { WV } & \text { Greenbrier } & 6 & 626 & 2 & 434 & 8 & 1,059 \\ \text { WV } & \text { Harrison } & 3 & 5,932 & 3 & 115 & 6 & 6,047 \\ \text { WV } & \text { Kanawha } & 15 & 6,850 & 11 & 5,021 & 26 & 11,870 \\ \text { WV } & \text { Lincoln } & 3 & 1,226 & - & - & 3 & 1,226 \\ \text { WV } & \text { Logan } & 12 & 7,205 & 14 & 11,336 & 26 & 18,541 \\ \text { WV } & \text { Marion } & 1 & 5,193 & 1 & 26 & 2 & 5,218 \\ & & & & & & \end{array}$




$\begin{array}{llllllll}\text { WV } & \text { Marshall } & 2 & 10,775 & - & - & 2 & 10,775 \\ \text { WV } & \text { Mason } & 1 & 584 & - & - & 1 & 584 \\ \text { WV } & \text { McDowell } & 32 & 3,001 & 14 & 2,517 & 46 & 5,519 \\ \text { WV } & \text { Mineral } & - & - & 2 & 86 & 2 & 86 \\ \text { WV } & \text { Mingo } & 19 & 4,593 & 12 & 8,589 & 31 & 13,182 \\ \text { WV } & \text { Monongalia } & 3 & 4,192 & 5 & 1,141 & 8 & 5,333 \\ \text { WV } & \text { Nicholas } & 5 & 1,310 & 6 & 3,087 & 11 & 4,397 \\ \text { WV } & \text { Preston } & 2 & 1,291 & - & - & 2 & 1,291 \\ \text { WV } & \text { Raleigh } & 16 & 5,533 & 3 & 3,098 & 19 & 8,631 \\ \text { WV } & \text { Randolph } & 1 & 392 & 1 & 4 & 2 & 396 \\ \text { WV } & \text { Tucker } & 1 & 2,561 & - & - & 1 & 2,561 \\ \text { WV } & \text { Upshur } & 2 & 858 & 1 & 42 & 3 & 899 \\ \text { WV } & \text { Wayne } & 3 & 4,063 & 1 & 1,041 & 4 & 5,104 \\ \text { WV } & \text { Webster } & 3 & 1,452 & 2 & 4,441 & 5 & 5,893 \\ \text { WV } & \text { Wyoming } & 15 & 3,741 & 3 & 1,576 & 18 & 5,316 \\ \text { WY } & \text { Campbell } & - & - & 12 & 415,924 & 12 & 415,924 \\ \text { WY } & \text { Carbon } & - & - & 1 & 261 & 1 & 261 \\ \text { WY } & \text { Converse } & - & - & 1 & 35,777 & 1 & 35,777 \\ \text { WY } & \text { Hot Springs } & - & - & 1 & 4 & 1 & \text { s } \\ \text { WY } & \text { Lincoln } & - & - & & 4,989 & 1 & 4,989 \\ & & & & 1 & & & \end{array}$




$\begin{array}{lccccccc}\text { WY } & \text { Sweetwater } & 1 & 3,501 & 3 & 7,191 & 4 & 10,692 \\ \text { U.S. } & & & & & & & \\ \text { Subtotal } & & \mathbf{5 8 3} & \mathbf{3 5 7 , 0 7 9} & \mathbf{8 5 2} & \mathbf{8 1 3 , 3 2 2} & \mathbf{1 , 4 3 5} & \mathbf{1 , 1 7 0 , 4 0 1}\end{array}$


Table 9: Coal Production by State and Mine Type

(Source: Annual Coal Report 2008, EIA)

\begin{tabular}{|c|c|c|c|c|c|c|}
\hline State & $\begin{array}{c}\text { Total } \\
\text { Number } \\
\text { of Mines }\end{array}$ & $\begin{array}{c}\text { Number } \\
\text { of Mines } \\
\text { U/G }\end{array}$ & $\begin{array}{l}\text { Number } \\
\text { of Mines } \\
\text { Surface }\end{array}$ & $\begin{array}{c}\text { Production } \\
\text { U/G (in } \\
\text { MST) }\end{array}$ & $\begin{array}{l}\text { Production } \\
\text { surface (in } \\
\text { MST) }\end{array}$ & $\begin{array}{c}\text { Total } \\
\text { Production } \\
\text { (in MST) }\end{array}$ \\
\hline Alabama & 59 & 8 & 51 & 12,281 & 8,330 & 20,611 \\
\hline Alaska & 1 & - & 1 & - & 1,477 & 1,477 \\
\hline Arizona & 1 & - & 1 & - & 8,025 & 8,025 \\
\hline Arkansas & 2 & 1 & 1 & 67 & 2 & 69 \\
\hline Colorado & 12 & 8 & 4 & 24,370 & 7,659 & 32,028 \\
\hline Illinois & 19 & 11 & 8 & 27,055 & 5,863 & 32,918 \\
\hline Indiana & 30 & 6 & 24 & 12,223 & 23,670 & 35,893 \\
\hline Kansas & 2 & - & 2 & - & 229 & 229 \\
\hline Kentucky & 469 & 216 & 253 & 69,474 & 50,849 & 120,323 \\
\hline Louisiana & 2 & - & 2 & - & 3,843 & 3,843 \\
\hline Maryland & 21 & 2 & 19 & 753 & 2,107 & 2,860 \\
\hline Mississippi & 1 & - & 1 & - & 2,842 & 2,842 \\
\hline Missouri & 2 & - & 2 & - & 247 & 247 \\
\hline Montana & 6 & 1 & 5 & 168 & 44,617 & 44,786 \\
\hline New Mexico & 5 & 1 & 4 & 7,046 & 18,599 & 25,645 \\
\hline $\begin{array}{l}\text { North } \\
\text { Dakota }\end{array}$ & 4 & - & 4 & - & 29,627 & 29,627 \\
\hline Ohio & 48 & 11 & 37 & 17,053 & 9,198 & 26,251 \\
\hline Oklahoma & 7 & 1 & 6 & 441 & 1,023 & 1,463 \\
\hline Pennsylvania & 266 & 51 & 215 & 53,318 & 12,095 & 65,414 \\
\hline Tennessee & 23 & 5 & 18 & 789 & 1,544 & 2,333 \\
\hline Texas & 11 & - & 11 & - & 39,017 & 39,017 \\
\hline Utah & 9 & 9 & - & 24,365 & - & 24,365 \\
\hline
\end{tabular}




$\begin{array}{lcccccr}\text { Virginia } & 114 & 65 & 49 & 15,806 & 8,907 & 24,712 \\ \text { West } & 301 & 186 & 115 & 88,369 & 69,409 & 157,778 \\ \text { Virginia } & 20 & 1 & 19 & 3,501 & 464,143 & 467,644 \\ \text { Wyoming } & & \mathbf{5 8 3} & \mathbf{8 5 2} & \mathbf{3 5 7 , 0 7 9} & \mathbf{8 1 3 , 3 2 2} & \mathbf{1 1 7 0 4 0 1} \\ \begin{array}{l}\text { U.S. } \\ \text { Subtotal }\end{array} & \mathbf{1 , 4 3 5} & & & & & \end{array}$


Table 10: Coal Production and Number of Mines by State and Coal Rank

\section{(Source: Annual Coal Report 2008, EIA)}

\begin{tabular}{|c|c|c|c|c|c|c|c|c|c|}
\hline State & $\begin{array}{l}\text { BIT- } \\
\text { No. } \\
\text { of } \\
\text { Mines }\end{array}$ & $\begin{array}{l}\text { BIT- } \\
\text { Production } \\
\text { (in TST) }\end{array}$ & $\begin{array}{l}\text { SUBBIT- } \\
\text { No. of } \\
\text { Mines }\end{array}$ & $\begin{array}{l}\text { SUBBIT- } \\
\text { Production } \\
\text { (in TST) }\end{array}$ & $\begin{array}{l}\text { Lignite- } \\
\text { No. of } \\
\text { Mines }\end{array}$ & $\begin{array}{l}\text { Lignite- } \\
\text { Production } \\
\text { (in TST) }\end{array}$ & $\begin{array}{l}\text { Anthracite- } \\
\text { No. of } \\
\text { Mines }\end{array}$ & $\begin{array}{l}\text { Anthracite- } \\
\text { Production } \\
\text { (in TST) }\end{array}$ & $\begin{array}{l}\text { Total } \\
\text { Production } \\
\text { (in MST) }\end{array}$ \\
\hline Alabama & 59 & 20,611 & - & - & - & - & - & - & 20,611 \\
\hline Alaska & - & - & 1 & 1,477 & - & - & - & - & 1,477 \\
\hline Arizona & 1 & 8,025 & - & - & - & - & - & - & 8,025 \\
\hline Arkansas & 2 & 69 & - & - & - & - & - & - & 69 \\
\hline Colorado & 9 & 24,773 & 3 & 7,256 & - & - & - & - & 32,028 \\
\hline Illinois & 19 & 32,918 & - & - & - & - & - & - & 32,918 \\
\hline Indiana & 30 & 35,893 & - & - & - & - & - & - & 35,893 \\
\hline Kansas & 2 & 229 & - & - & - & - & - & - & 229 \\
\hline Kentucky & 469 & 120,323 & - & - & - & - & - & - & 120,323 \\
\hline Louisiana & - & - & - & - & 2 & 3,843 & - & - & 3,843 \\
\hline Maryland & 21 & 2,860 & - & - & - & - & - & - & 2,860 \\
\hline Mississippi & - & - & - & - & 1 & 2,842 & - & - & 2,842 \\
\hline Missouri & 2 & 247 & - & - & - & - & - & - & 247 \\
\hline
\end{tabular}




\begin{tabular}{|c|c|c|c|c|c|c|c|c|c|}
\hline Montana & - & - & 5 & 44,431 & 1 & 355 & - & - & 44,786 \\
\hline New Mexico & 1 & 7,046 & 4 & 18,599 & - & - & - & - & 25,645 \\
\hline $\begin{array}{l}\text { North } \\
\text { Dakota }\end{array}$ & - & - & - & - & 4 & 29,627 & - & - & 29,627 \\
\hline Ohio & 48 & 26,251 & - & - & - & - & - & - & 26,251 \\
\hline Oklahoma & 7 & 1,463 & - & - & - & - & - & - & 1,463 \\
\hline Pennsylvania & 200 & 63,713 & - & - & - & - & 66 & 1,701 & 65,414 \\
\hline Tennessee & 23 & 2,333 & - & - & - & - & - & - & 2,333 \\
\hline Texas & - & - & - & - & 11 & 39,017 & - & - & 39,017 \\
\hline Utah & 9 & 24,365 & - & - & - & - & - & - & 24,365 \\
\hline Virginia & 114 & 24,712 & - & - & - & - & - & - & 24,712 \\
\hline $\begin{array}{l}\text { West } \\
\text { Virginia }\end{array}$ & 301 & 157,778 & - & - & - & - & - & - & 157,778 \\
\hline Wyoming & 1 & 261 & 19 & 467,383 & - & - & - & - & 467,644 \\
\hline $\begin{array}{l}\text { U.S. } \\
\text { Subtotal }\end{array}$ & 1,319 & 553,872 & 31 & 539,145 & 19 & 75,684 & 66 & 1,701 & $1,170,401$ \\
\hline
\end{tabular}


Table 11: Recoverable Coal reserves and Average Percentage at producing mines by State

(Source: Annual Coal Report 2008, EIA)

\begin{tabular}{|c|c|c|c|c|c|c|}
\hline State Name & FIPS & $\begin{array}{c}\text { Recoverable Coal } \\
\text { Reserves } 2008\end{array}$ & $\begin{array}{l}\text { Average } \\
\text { Recovery } \\
\%, 2008\end{array}$ & $\begin{array}{c}\text { Recoverable } \\
\text { Coal Reserves } \\
2007\end{array}$ & $\begin{array}{c}\text { Average } \\
\text { Recovery \%, } \\
2007\end{array}$ & $\begin{array}{l}\text { \% Change Recoverable } \\
\text { Coal Reserves (2008 and } \\
\text { 2007) }\end{array}$ \\
\hline Alabama & 01 & 330 & 57.98 & 327 & 57.15 & 1 \\
\hline Alaska & 02 & W & $\mathrm{W}$ & W & $\mathrm{W}$ & - \\
\hline Arizona & 04 & $\mathrm{~W}$ & $\mathrm{~W}$ & $\mathrm{~W}$ & $\mathrm{~W}$ & W \\
\hline Arkansas & 05 & W & W & W & W & - \\
\hline Colorado & 08 & 325 & 70.92 & 328 & 72.85 & -0.9 \\
\hline Illinois & 17 & 1189 & 60.43 & 1286 & 61.99 & -7.5 \\
\hline Indiana & 18 & 421 & 69.52 & 401 & 67.58 & 5.1 \\
\hline Kansas & 20 & W & W & W & W & W \\
\hline Kentucky & 21 & 1167 & 58.37 & 1182 & 59.91 & -1.3 \\
\hline Louisiana & 22 & W & $\mathrm{W}$ & W & $\mathrm{W}$ & W \\
\hline Maryland & 24 & 22 & 74.01 & 24 & 61.75 & -9.1 \\
\hline Mississippi & 28 & W & W & W & W & W \\
\hline Missouri & 29 & W & W & W & W & W \\
\hline Montana & 30 & 925 & 89.55 & 1251 & 88.01 & -26.1 \\
\hline
\end{tabular}




$\begin{array}{lcccccc}\text { New Mexico } & 35 & 605 & 88.44 & 483 & 90.64 & 25.4 \\ \text { North Dakota } & 38 & 1225 & 90.6 & 1252 & 90.64 & -2.2 \\ \text { Ohio } & 39 & 308 & 69.32 & 333 & 73 & -7.6 \\ \text { Oklahoma } & 40 & 85 & 54.74 & 155 & 52.67 & -45.6 \\ \text { Pennsylvania } & 42 & 526 & 71.96 & 532 & 71.69 & -1.2 \\ \text { Tennessee } & 47 & 10 & 75.05 & 12 & 79.31 & -16.9 \\ \text { Texas } & 48 & 752 & 90.82 & 737 & 90.04 & 2 \\ \text { Utah } & 49 & 212 & 56.97 & 211 & 57.92 & 0.4 \\ \text { Virginia } & 51 & 217 & 55.8 & 256 & 56.25 & -15.4 \\ \text { Washington } & 53 & - & - & - & - & - \\ \text { West Virginia } & 54 & 1908 & 57.24 & 1828 & 57.49 & 4.4 \\ \text { Wyoming } & 56 & 7010 & 91.52 & 7330 & 91.36 & -4.4 \\ \text { U.S. Total } & & \mathbf{1 7 8 7 5} & \mathbf{7 9 . 6 4} & \mathbf{1 8 5 8 4} & \mathbf{7 9 . 9 2} & \mathbf{- 3 . 8}\end{array}$

